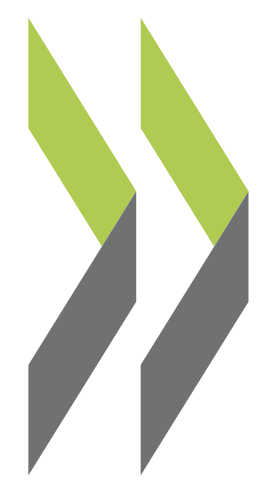

OECD Economics Department Working Papers No. 152

Estimating Potential Output, Output Gaps and Structural Budget Balances
Claude Giorno,

Pete Richardson,

Deborah Roseveare, Paul van den Noord 


\section{OCDE/GD(95)1}

\section{ECONOMICS DEPARTMENT \\ WORKING PAPERS}

NO. 152

\section{ESTIMATING POTENTIAL OUTPUT, OUTPUT GAPS AND STRUCTURAL BUDGET BALANCES}

by

Claude Giorno, Pete Richardson, Deborah Roseveare and Paul van den Noord

ORGANISATION FOR ECONOMIC CO-OPERATION AND DEVELOPMENT

Paris 1995

COMPLETE DOCUMENT AVAILABLE ON OLIS IN ITS ORIGINAL FORMAT 


\section{ESTIMATING POTENTIAL OUTPUT, OUTPUT GAPS AND STRUCTURAL BUDGET BALANCES}

This paper reviews the methods used for estimating potential output in OECD countries and the use of the resulting output gaps for the calculation of structural budget balances. The "split time trend" method for estimating trend output that was previously used for calculating structural budget balances is compared with two alternative methods, smoothing real GDP using a Hodrick Prescott filter and estimating potential output using a production function approach. It is concluded that the production function approach for estimating potential output provides the best method for estimating output gaps and for calculating structural budget balances, with the results obtained by smoothing GDP providing a cross check. New tax and expenditure elasticities, along with the potential output gaps, are used to derive structural budget balances.

$$
\text { ****** }
$$

\section{ESTIMATION DE LA PRODUCTION POTENTIELLE, DES ÉCARTS DU PRODUCTION ET LES SOLDES BUDGÉTAIRES STRUCTURELS}

Ce document passe en revue les différentes méthodes utilisées pour estimer la production potentielle dans les pays de l'OCDE et l'utilisation des écarts de production qui a dêcoulent pour le calcul des soldes budgétaires structurels. La méthode utilisant la segmentation de la tendance temporelle pour estimer la production potentielle et qui servait précédemment á calculer les soldes budgétaires structurels est comparée à deux autres méthodes : le lissage du PIB réel à l'aide d'un filtre Hodrick-Prescott et l'estimation de la production potentielle sur la base d'une fonction de production. Il en ressort que l'estimation de la production potentielle par l'approche fonction de production a s'avère être la meilleure méthode pour estimer les écarts de production et pour calculer les soldes budgétaires structurels, les résultats obtenus par lissage du PIB étant utilisés comme moyens de vérification. Pour estimer les soldes budgétaires structurels, on utilise de nouvelles élasticités des prelevement et des dépenses et les écarts par rapport a la production potentielle.

\section{Copyright OECD, 1995.}

Applications for permission to reproduce or translate all, or part of, this material should be made to : Head of Publications Service, OECD, 2 Rue André Pascal, 75775 Paris Cedex 16, France. 


\section{Table of Contents}

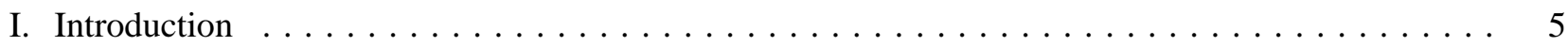

II. Estimating Potential Output and Output Gaps $\ldots \ldots \ldots \ldots \ldots \ldots \ldots \ldots \ldots \ldots$

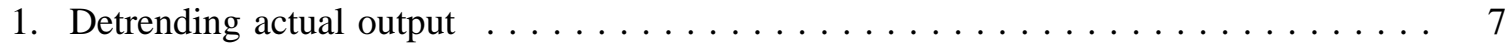

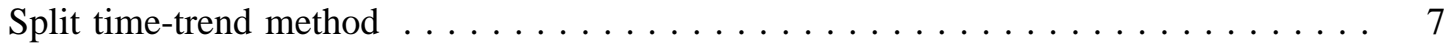

Smoothing GDP using a Hodrick-Prescott filter $\ldots \ldots \ldots \ldots \ldots \ldots \ldots \ldots$

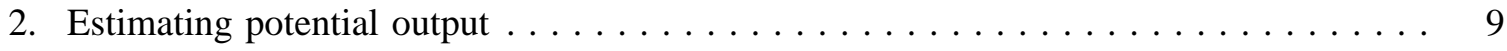

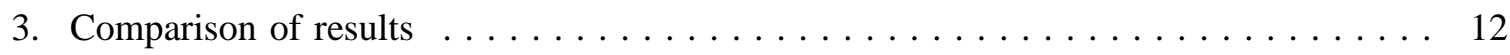

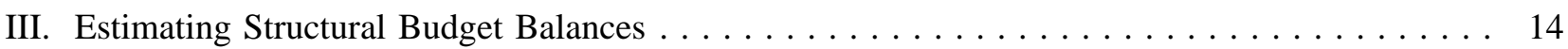

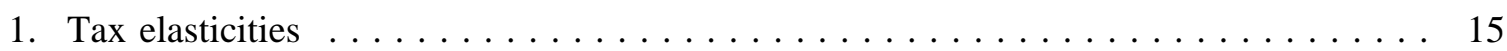

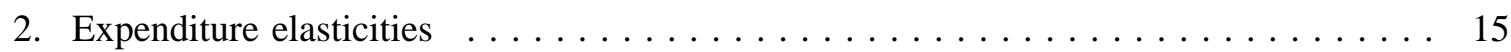

3. Structural budget balances: results $\ldots \ldots \ldots \ldots \ldots \ldots \ldots \ldots \ldots \ldots \ldots$

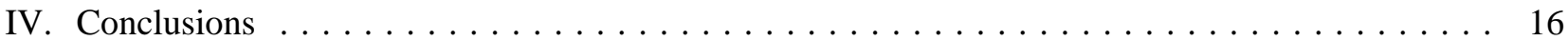

Annex 1: Determination of Income-tax and Social Security Contributions Elasticities . . . . . . 47

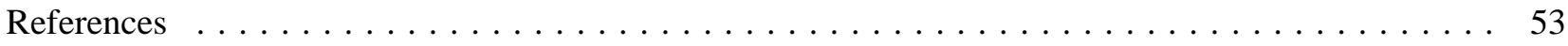




\section{Tables}

1. Contributions to growth in business sector potential output and NAWRUs

2. Growth rates and output gaps under different methods

3. Regression-based tax elasticities

4. Tax elasticities: previous and new

5. Cyclical effects on government spending

6. Unemployment expenditure and total general government expenditure

7. Comparison of actual and structural budget balances

8. Changes in fiscal balances

9. Cyclical budget balances

Box: Decomposition of growth in potential output

\section{Figures}

1. Output growth and output gaps

2. General government structural balances as a percentage of trend GDP

\section{Annex Tables}

A1. Gross-earnings elasticities of income tax and social security contributions

A2. Output elasticities of income tax and social security contributions in 1991

A3. Output elasticities of income tax and social contributions 


\title{
ESTIMATING POTENTIAL OUTPUT, OUTPUT GAPS AND STRUCTURAL BUDGET BALANCES
}

\author{
Claude Giorno, Pete Richardson, Deborah Roseveare and Paul van den Noord ${ }^{1}$
}

\section{Introduction}

1. Measuring productive potential and the position of output in relation to potential (i.e. the output gap) are important elements in the OECD Secretariat's economic assessments and provide a number of key insights into macroeconomic performance. For the short-term, measures of the size and persistence of existing output gaps provide a useful guide to the balance between supply and demand influences and hence the assessment of inflation pressures ${ }^{2}$. For the medium term, measures of productive potential -- those which embody information about trend developments in the stock of capital, the labour force and technological change -- provide a useful guide to the aggregate supply capabilities of the economy and hence the assessment of the sustainable non-inflationary growth paths of output and employment.

2. Indicators of the output cycle also provide a means of "looking-through" short-term transitory influences, to identify any build-up in underlying imbalances or structural positions in the macroeconomy. This is particularly important for fiscal analysis, where developments in underlying structural budget deficits continue to be a cause for concern in many Member countries and estimates of the output gap can be used to identify and isolate the impact of cyclical factors of the budget. Thus, short-term improvements in budget positions due to a pick-up in economic activity may be reversed as activity slows down and should therefore not be seen as an underlying improvement in public finances: if underlying structural deficits imply increasingly unsustainable public debt positions, this indicates the need for effort and specific policy actions to redress the situation. Changes in the structural deficit may also provide some indication of the degree of stimulus or restraint that the government wishes to provide to demand (fiscal impulse) over and above that provided by automatic stabilisers ${ }^{3}$, or a measure of the degree of fiscal consolidation.

1. The authors would like to acknowledge the useful comments and contributions received from many members of the Economics Department and in particular, Willi Leibfritz, Mike Feiner, Jorgen Elmeskov and Richard Herd. Debbie Bloch, Marie-Christine Bonnefous, Jackie Gardel, Tara Gleeson, and Anick Lotrous provided invaluable technical assistance.

2. Recent OECD work on the links between demand pressure and price and wage inflation is summarised by Elmeskov (1993), Turner et al. (1993) and Turner et al. (forthcoming).

3. As the change in the structural deficit is only a very rough indicator of discretionary policy, other indicators have been suggested to measure fiscal stance (see Blanchard, 1990). 
3. Given the importance attached to measures of potential and cyclical positions, the OECD Secretariat has recently completed a major review of the estimation methods used in its conjunctural assessments and the construction of its indicators of structural budget balances. In the past, two different forms of analysis have typically been used.

4. First, in its modelling work and country-specific conjunctural assessments, emphasis has been given to measures of potential output which are structural and depend on a production function framework, drawing on information concerning the capital stock, working population, trend participation rates, structural unemployment and factor productivity developments. Such measures may be qualified, sometimes heavily, by the judgement of country specialists in the OECD Secretariat. Specific weight can also be given to the perceived limits to sustainable non-inflationary growth associated with the labour market, making use of information about both actual rates and underlying natural rates of unemployment (more precisely, the socalled non-accelerating wage rate of unemployment, or NAWRU).

5. Second, the OECD Secretariat's fiscal indicators have previously been based on measures of trend output and cycle derived by the application of time-series methods to actual developments in real GDP ${ }^{4}$. Though parsimonious in the use of information, the previous method used (known as "split time-trend") was relatively mechanical and therefore had some difficulty in dealing with frequent structural changes and sometimes required ad hoc judgements about the current cycle to keep results within reasonable bounds. It was of particular concern that the split time-trend method's weaknesses were most apparent for the period of most interest to policy-makers -- the present and the near future -- and that it took no account of the constraints to trend growth due to inflation pressures.

6. For these reasons, and because it would seem preferable to use a single indicator in the assessment of employment and inflation developments and structural budget balances, the OECD Secretariat has reviewed and revised its estimation methods to provide a single measure of potential output. Specifically, the chosen measure is one which represents the levels of real GDP, and associated rates of growth, which are sustainable over the medium term at a stable rate of inflation. Nonetheless, it is clear from this work and the wide range of analytic and survey-based indicators which are available, that significant margins of error are involved in their estimation and use. Reliance therefore cannot wholly be placed on a single measure of potential or trend output and related indicators must therefore be treated with due caution. ${ }^{5}$

7. Details of the method the Secretariat has now adopted are set out in the rest of this paper. Three estimation methods -- two forms of GDP smoothing (including the method previously used by the Secretariat) and the preferred production function-based method -- are reviewed in Part II. This includes an evaluation of the respective strengths and weaknesses and comparative results for three sets of trend output and output gap estimates. The calculation of structural budget deficits using the potential output estimates and revised tax and expenditure elasticity assumptions are presented in Part III, together with comparative results based on the former method and elasticities and an assessment of the implications for fiscal policy. Summary conclusions are provided in Part IV.

4. A detailed background to previous work on fiscal indicators is given by Price and Muller (1984). See also Chouraqui et al. (1990).

5. For this reason, a complementary time-series based measure of trend GDP is used to cross-check the evolution of the potential output estimates. 


\section{Estimating Potential Output and Output Gaps}

8. A variety of methods can be used to calculate trend or potential output and a corresponding output gap, but this paper concentrates on comparisons of the split time-trend method previously used by the Secretariat to calculate structural budget balances and two alternatives ${ }^{6}$. The first alternative involves smoothing real GDP using a Hodrick-Prescott (HP) filter. As with the split time-trend method, the HP filter is a statistical technique for determining the trend in real GDP, by calculating a weighted moving average of GDP over time (and is therefore subject to similar limitations). The second approach is to estimate potential output, based on a production function relationship and the factor inputs that are available to the economy. This requires more data inputs and more assumptions about economic inter-relationships, but on the other hand is less mechanical and more directly relevant to macroeconomic assessment.

\section{Detrending actual output}

\section{Split time-trend method}

9. Previous work by the Secretariat on fiscal indicators has used a split time-trend method to calculate trend output (average output growth) during each cycle, where the cycle is defined as the period between peaks in economic growth ${ }^{7}$. The peaks themselves generally occur where the positive output gap is largest, using the following formula:

$$
\ln Y_{t}=\alpha_{o}+\sum_{i=1}^{n} \alpha_{i} T_{i}+e_{t}
$$

where:

$$
\begin{aligned}
\mathrm{Y}_{\mathrm{t}} & =\text { real GDP } \\
\alpha_{\mathrm{i}} & =\text { trend growth coefficient } \\
\mathrm{T}_{\mathrm{i}} & =\text { segment of the broken time trend } \\
\mathrm{e} & =\text { error term }
\end{aligned}
$$

This specification allows estimated trend growth to change between cycles, but not within each cycle. While in theory this method is straightforward, in practice determining where the peaks in the cycle occur is more complicated, using the residuals obtained by regressing GDP on a time trend, in an iterative process: hence the trend determines the peaks, but the peaks also determine the trend.

10. The main advantage of this method is that once the peaks have been identified and the cycle thus defined, output gaps are simple to calculate and are symmetric over each complete cycle. But there are two major shortcomings. Firstly, the method imposes a deterministic trend during the course of each cycle and permits structural breaks to occur only at the peak of the cycle. This is quite inconsistent with a wide range of theoretical and empirical analyses that demonstrate that trend output is stochastic rather than deterministic (for example, see Nelson and Plosser (1982)). Furthermore, to the extent that discrete structural breaks

6. A number of other possible approaches are summarised in Canova (1993). See also Nicoletti and Reichlin (1993).

7. See, for example, Chouraqui et al. (1990). 
occur, they represent permanent shocks, and there is no reason to expect them to be correlated with any particular point in the cycle.

11. Secondly, for the current cycle, the timing and the size of the next peak is likely to be unknown, so the method outlined above can only be applied by making assumptions about the position and timing of the next peak. In practice, current trend output has to be projected judgementally, taking into account on an ad hoc basis available information about labour force growth, capital formation and productivity. Such a judgmental projection also affects past values of the trend, back to the end of the last complete cycle. Thus, for the period of most interest to policy makers -- the present and the near future -- the split time-trend method relies on ad hoc judgements about the evolution of trend output. These may be closer in spirit to a potential output approach, but without the rigour of the more formal procedure described below. In the Secretariat's judgement, the drawbacks and the lack of transparency of this approach constitute an argument that it should be replaced.

\section{Smoothing GDP using a Hodrick-Prescott filter}

12. The GDP smoothing approach using an HP filter fits a trend through all the observations of real GDP, regardless of any structural breaks that might have occurred, by making the regression coefficients themselves vary over time. This is done by finding a trend output that simultaneously minimises a weighted average of the gap between output and trend output, at any point in time, and the rate of change in trend output at that point in time. More precisely, the trend $\mathrm{Y}^{*}$ for $\mathrm{t}=12 \ldots . \mathrm{T}$ is estimated to minimise

$$
\sum_{t=1}^{T}\left(\operatorname{In} Y_{t}-\operatorname{In} Y_{t}^{*}\right)^{2}+\lambda \sum_{t=2}^{T-1}\left[\left(\operatorname{In} Y_{t+1}^{*}-\operatorname{In} Y_{t}^{*}\right)-\left(\operatorname{In} Y_{t}^{*}-\operatorname{In} Y_{t-1}^{*}\right)\right]^{2}
$$

where $\lambda$ is the weighting factor that controls how smooth the resulting trend line is. A low value of $\lambda$ will produce a trend that follows actual output more closely, whereas a high value of $\lambda$ reduces sensitivity of the trend to short-term fluctuations in actual output and, in the limit, the trend tends to the mean growth rate for the whole estimation period.

13. In common with split time-trend methods, this approach requires only actual observations of GDP, but a major criticism is the arbitrary choice of $\lambda$ which determines the variance of the trend output estimate $^{8}$. From a statistical point of view, $\lambda$ must be arbitrarily chosen, because any non-stationary series (integrated of order 1) can be decomposed into an infinite number of non-stationary trend and stationary cycle combinations. Thus far, no satisfactory statistical criterion has been developed to identify which trend/cycle decompositions might be better than others. For many applications in the literature, $\lambda$ is set to the specific value originally chosen by Hodrick and Prescott $(\lambda=1600)$, and which seems to have become a de facto "industry standard" 9 , although this choice was based on a prior view about the ratio of the variance of the cycle to the variance of the trend (see Hodrick and Prescott 1980), and was also dependent on the data series being adjusted ${ }^{10}$.

8. Specifically, the variance of trend output falls as $\lambda$ increases, whilst the amplitude of the corresponding output gap increases with $\lambda$.

9. Problems arising from the indiscriminate use of 1600 for GDP and other data series are discussed in Canova (1993).

10. Later, Prescott and Kydland (1990) justified their choice of $\lambda$ as producing a trend that most closely corresponded to the line that students would fit through GDP by hand and eye. 
14. Since the choice of $\lambda$ remains a key judgement, there are three possible decision criteria. The first would be to follow Hodrick and Prescott's approach and choose a constant ratio of the variances of trend output and actual output. This approach would generate a different $\lambda$ value for each country and would mean that countries whose actual output fluctuates more would also show greater fluctuation in trend. A second approach would be to impose a uniform degree of smoothness and the same variance in trend output for each country. However, the difficulty with both these criteria is that they ignore the possibility that some countries respond with greater flexibility to economic shocks than others. This would affect how closely trend output would follow actual output.

15. A third approach is to choose a value of $\lambda$ that generates a pattern of cycles which is broadly consistent with prior views about past cycles in each country. Such a criteria is judgemental and is able to incorporate (limited) information about the past, but it is also less transparent than the other criteria. This method generally leads to the choice of values of $\lambda$ which are small and relatively uniform across countries $^{11}$.

16. As with the split time-trend method, the HP filter method also has an end-point problem. In part this reflects the fitting of a trend line symmetrically through the data: if the beginning and the end of the data set do not reflect similar points in the cycle, then the trend will be pulled upwards or downwards towards the path of actual output for the first few and the last few observations. For example, for those countries which are slower to emerge from recession, an HP filter will tend to underestimate trend output growth for the current period. This problem can be reduced by using projections which go beyond the short-term to the end of the current cycle. For example, in the current study, GDP projections from the most recent OECD medium-term reference scenario have been used to extend the period of estimation until 2000 to give more stability to estimates for the current and short-term projections period. In effect this amounts to giving specific weight to judgements about potential and output gaps embodied in those projections, with HP filter estimates tending towards potential, provided the output gap is closed by the end of the extended sample period.

17. A further possible weakness of the method is the treatment of structural breaks, which are typically smoothed over by the HP filter: moderating the break when it occurs, but spreading its effect out over several years, depending on the value of $\lambda$. This may not be inappropriate if the break occurs gradually over time but is problematic in the case of large discrete changes in output levels.

\section{Estimating potential output}

18. From the point of view of macroeconomic analysis, the most important limitation of both the above smoothing methods is that they are largely mechanistic and bring to bear no information about the structural constraints and limitations on production through the availability of factors of production or other endogenous influences. Thus, trend output growth projected by time-series methods may be inconsistent (too high or too low) with what is known or being assumed about the growth in capital, labour supply or factor productivity or may be unsustainable because of inflationary pressures. The preferred "potential output" approach attempts to overcome these shortcomings whilst adjusting also for the limiting influence of demand pressure on employment and inflation. It does so in a structural framework; one in which consistent judgement can also be exercised on some of the key elements.

11. In the present study a value of $\lambda=25$ was used for most OECD Member countries. 
Decomposition of Growth in Potential Output

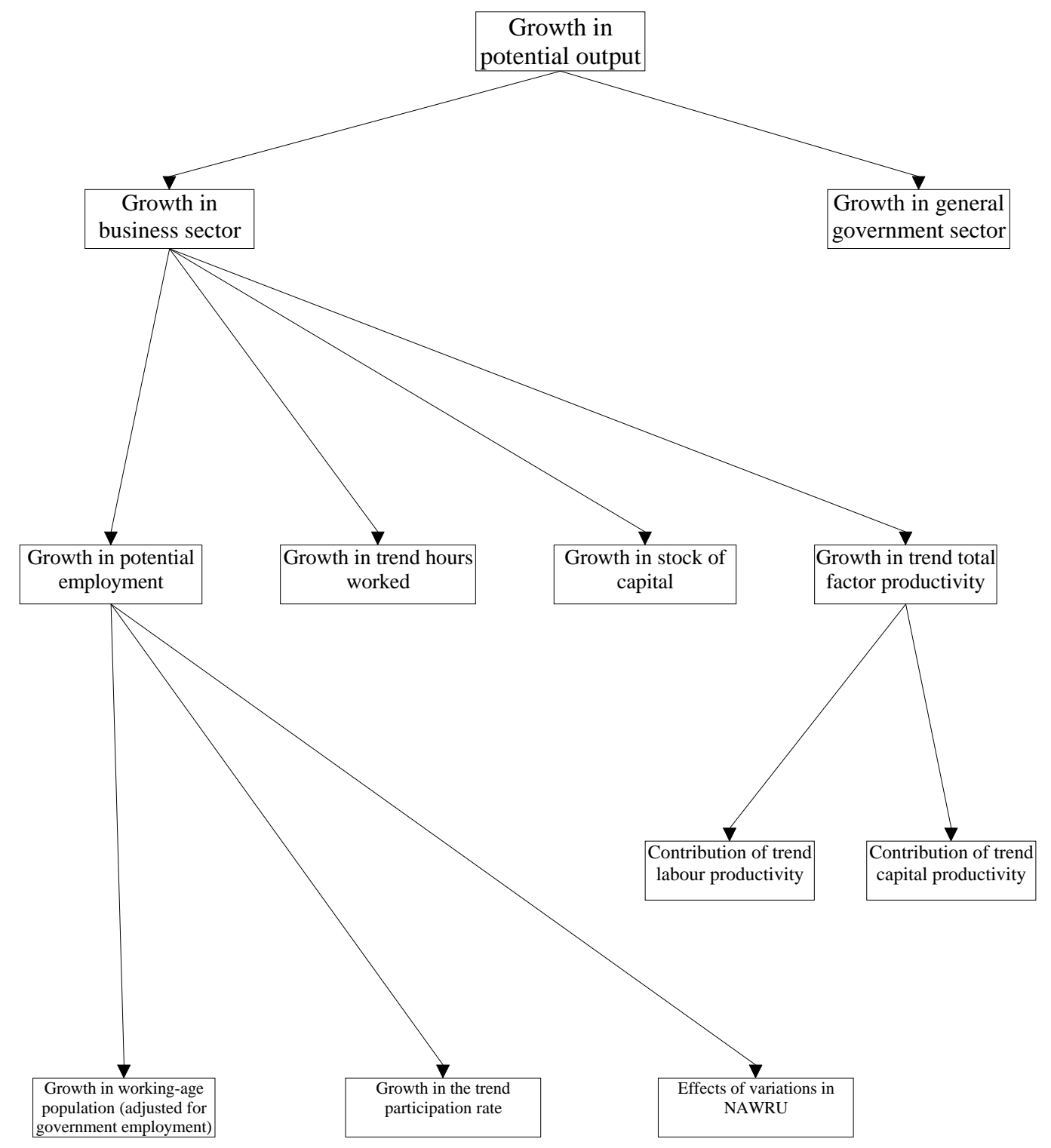


19. The framework of the OECD Secretariat's analysis of potential output is broadly that adopted in its supply modelling work, as previously described by Torres and Martin (1989) and Torres et al. (1989). In its simplest form, a two-factor Cobb-Douglas production function for the business sector is estimated for each country, for given sample average labour shares. The estimated residuals from these equations are then smoothed to give measures of trend total factor productivity. Potential output for the business sector is then calculated by combining this measure of trend factor productivity with the actual capital stock and estimates of "potential" employment, using the same estimated production function. The chosen measure of "potential" employment is defined as the level of labour resources that might be employed without resulting in additional inflation. In effect, this amounts to adjusting the actual labour input used in the estimated production function for the gap between actual unemployment and the estimated NAWRU level. More specifically, the estimation method follows the following steps:

The estimated business-sector production function is assumed to be of the form:

$\begin{aligned} & \text { LnY }=\operatorname{LnA}+\alpha \operatorname{LnN}+(1-\alpha) \operatorname{LnK}+\operatorname{LnE} \\ & \text { i.e. } \quad \mathrm{y}=\mathrm{a}+\alpha \mathrm{n}+(1-\alpha) \mathrm{k}+\mathrm{e} \\ & \text { where: } \mathrm{Y}=\text { business-sector value added } \\ & \mathrm{N}=\text { actual business-sector labour input } \\ & \mathrm{K}=\text { actual business-sector capital input (excluding housing) } \\ & \mathrm{E}=\text { total factor productivity } \\ & \alpha=\text { average labour share parameter } \\ & \text { lower-case letters indicate natural logarithms. }\end{aligned}$

20. For a given value of the labour share, $\alpha$, the e series is calculated and then smoothed using a Hodrick-Prescott filter to provide a measure of trend factor productivity, $\mathrm{e}^{*}$. Next, the trend factor productivity series, $\mathrm{e}^{*}$, is substituted back into the production function along with actual capital stock, $\mathrm{k}$, and "potential" employment, $\mathrm{n}^{*}$, to provide a measure of the log of business-sector potential, $\mathrm{y}^{*}$, as:

$$
\mathrm{y}^{*}=\mathrm{a}+\alpha \mathrm{n}^{*}+(1-\alpha) \mathrm{k}+\mathrm{e}^{*}
$$

where the level of potential employment in the business sector, $\mathrm{N}^{*}$, is then calculated as:

$$
\mathrm{N}^{*} \quad=\quad \text { LFS }(1-\mathrm{NAWRU})-\mathrm{EG}
$$

where: LFS $=$ smoothed labour force (the product of the working age population and the trend participation rate)

NAWRU $=$ estimated non-accelerating wage rate of unemployment

$\mathrm{EG}=$ employment in the government sector.

21. The identification of appropriate measures of the NAWRU draws on a number of different sources of information. As the starting point, a set of estimates is derived using the method described by Elmeskov (1993) and Elmeskov and MacFarlan (1993). This method essentially assumes that the change in wage inflation is proportional to the gap between actual unemployment and the NAWRU. Assuming also that the NAWRU changes only gradually over time, successive observations on the changes in inflation and actual unemployment rates can then be used to calculate a time series corresponding to the implicit value of the NAWRU. More specifically, it is assumed that the rate of change of wage inflation is proportional to the gap between actual unemployment and the NAWRU, thus:

$$
\mathrm{D}^{2} \log \mathrm{W}=-\mathrm{a}(\mathrm{U}-\mathrm{NAWRU}) \quad \mathrm{a}>0
$$


where $\mathrm{D}$ is the first-difference operator and $\mathrm{W}$ and $\mathrm{U}$ are the levels of wages and unemployment, respectively. Assuming the NAWRU to be constant between any two consecutive time periods, an estimate of a can be calculated as:

$$
a=-D^{3} \log W / D U
$$

which, in turn, is used to give the estimated NAWRU as:

$$
\mathrm{NAWRU}=\mathrm{U}-\left(\mathrm{DU} / \mathrm{D}^{3} \log \mathrm{W}\right) * \mathrm{D}^{2} \log \mathrm{W}
$$

22. The resulting series are then smoothed to eliminate erratic movements ${ }^{12}$. As illustrated by Elmeskov (op. cit.), such measures of the NAWRU come close to the results of comparable methods which use alternative Okun or Beveridge curve relationships as a starting point. For a number of major countries, this information was then supplemented by estimates based on recent wage equation estimates embedded in the supply blocks of the INTERLINK model (see Turner et al., 1993), along with a range of previous estimates. The broad set of NAWRU estimates were then cross-checked by OECD Secretariat country experts and modified where additional country information was available.

23. Potential output for the whole economy is finally obtained by adding actual value added in the government sector to business-sector potential output. Thus, for want of a superior alternative measure, actual value added in the government sector is taken to be equal to potential output in that sector. The calculation of potential output growth and the decomposition into its various components is illustrated schematically in the Box, and the decomposition into main components is provided in Table 1.

24. For Japan, a slightly different approach is used from the one outlined above. In particular, the most recent Secretariat estimates of the business sector production function for Japan (see Turner et al., op. cit.) suggest that the Cobb-Douglas production function is inappropriate and instead a CES production function is used, one with an estimated elasticity of substitution between capital and labour of 0.4. In this case, the decomposition of potential output growth into its component parts is more complex than shown above.

\section{Comparison of results}

25. A general comparison of growth rates and output gaps for each country of estimated potential output with previous split time-trend estimates and HP trend estimates is provided in Table 2 and Figure 1. There are several general features to note. Firstly, the symmetry properties are different. The calculation of trend output using a split time-trend or HP filter imposes the property that the output gaps are symmetric over the full estimation period (i.e. they sum to zero), even if the economy is not at the same point in the cycle at the beginning and the end of the period ${ }^{13}$. In contrast, such symmetry is not imposed on the measures of potential but will depend on the relative positions of actual and NAWRU rates of unemployment -- in particular the potential measure will only be exactly symmetric if the NAWRU estimate is exactly equal to average unemployment over the cycle.

12. To the extent that wage inflation is affected, not only by the level of unemployment but also its year-to-year changes, the derived short-run indicator will tend to move with actual unemployment and may thus differ from the long-run NAWRU obtained for a constant rate of unemployment.

13. In fact, since the HP filter is applied to lnGDP, the resulting output gaps calculated from GDP and trend GDP are not quite symmetric. The asymmetry grows as $\lambda$ rises, but for the chosen values of $\lambda$ presented here, this asymmetry is negligible. 
26. Another important feature is that potential output growth rates may fluctuate from year to year, more so than trend growth rates derived from output smoothing. Using the decomposition of contributions to potential growth shown in Table 1, the non-cyclical factors contributing to such variability are seen to vary from country to country. The three most important factors are variations in the NAWRU, the growth of capital stock and working-age population.

27. Since the NAWRU assumptions are necessarily imprecise and subject to a range of measurement problems it is useful to provide some sensitivity analysis for the resulting estimates of potential output and output gaps. In practice, the consequences of choosing a higher or lower NAWRU estimate on the estimated level of potential output are quite straightforward and are inversely related to the "labour share" of business sector output. Thus for the United States, with an average labour share of 68 per cent, assuming a NAWRU estimate which is $1 / 2$ per cent lower would raise the level of business sector potential output by 0.3 to 0.4 per cent, implying a corresponding level shift in the estimate of the gap between actual and potential GDP. Since this entails a shift in the level of potential GDP, the consequences for the average growth rate of potential output are negligible or zero. Since the average labour shares of other OECD countries typically vary between 65 to 75 per cent, their sensitivity to variations in NAWRU estimates are broadly similar to the United States case.

28. Comparing across output gap estimates in Figure 1, the main turning points and broad characteristics are seen, with some exceptions, to be broadly consistent for each country, though this is also a reflection of the major peaks and troughs in the growth of actual GDP. Over the sample period up to the start of the recent recession, the broad developments shown for most countries are highly correlated across measures, though with varying degrees of differences. In general, the HP filter-based measures tend to suggest cycles of slightly lesser amplitude and hence smaller output gaps than either potential or split time trend measures, reflecting the specific values of the $\lambda$ parameter used in the calculation. For most countries however, these differences do not seem to be large.

29. There are however a number of exceptions -- most notably for Austria, Finland, Japan, Norway and Spain -- where one or other measure behaves differently over some part of the sample. For the potential measure, the factors responsible can be readily identified with specific information and assumptions about non-cyclical or discrete changes in supply factors -- shifts in working hours, capital stock, participation rates, working population and/or the NAWRU estimates (as reported in Table 1). For the time series measures, these factors are not taken into account and the trend estimates simply reflect developments in GDP over time, given the chosen values of the smoothing parameter or the dating of the peaks, depending on the method used.

30. Over the period of more immediate concern, -- the recent past, the present and the projection period -- there is clearer evidence of systematic differences, reflecting the inherent problems in projecting the split time trend through to the end of the current cycle. Most noticeably, for Canada, France, Italy and Japan, the split time trend measures give much larger estimates of the output gap than either potential or the HP filter for the current projection period. Moreover in each of these cases the measures given by potential and HP methods are much closer over the recent past.

31. These results underscore the need for consistent judgement and hence a framework of assessment in which the behavioural assumptions underlying the projection can be clearly identified and, as necessary, challenged and adjusted according to new information i.e. a process which goes beyond the mechanical application of time series methods to GDP. The latter are nonetheless useful where significant deviations of the potential estimates from a suitably calibrated trend may signal the need for a closer examination of the underlying macroeconomic and structural assumptions being made -- either about the estimate of potential or the medium-term projections. For these reasons, the preferred approach is to use the potential 
measure, subject to its plausibility being checked against a suitably selected time series estimate of trend GDP.

\section{Estimating Structural Budget Balances}

32. The overall purpose of adjusting government balances for changes in economic activity is to get a clearer picture of the underlying fiscal situation and to use this as a guide to fiscal policy analysis. The structural budget balance reflects what government revenues and expenditures would be if output was at its potential level and therefore does not reflect cyclical developments in economic activity. In contrast, the actual budget balance does reflect the cyclical component of economic activity and therefore fluctuates around the structural budget balance. In practice, the structural budget balance must be estimated by taking actual government revenues and expenditures and breaking them into an estimated cyclical component and an estimated structural component. More precisely, the structural budget balance measures what the balance of tax revenues less government expenditure would be if actual GDP corresponded to potential GDP. Thus:

$$
\mathrm{B}^{*}=\sum \mathrm{T}_{\mathrm{i}}^{*}-\mathrm{G}^{*}+\text { capital spending }
$$

where: $\mathrm{B}^{*}=$ structural budget balance

$\mathrm{T}_{\mathrm{i}}^{*}=$ structural tax revenues for the ith category of tax

$\mathrm{G}^{*}=$ structural government expenditures (excluding capital spending)

33. In practice, the components of the structural budget balance must be estimated from actual tax revenues (broken into four categories: corporate tax, income tax, social security contributions, and indirect taxes) and government expenditures using the property that each component of the budget is adjusted proportionately to the ratio of potential output to actual output, as determined by its elasticity. Thus:

$$
\frac{T_{i} *}{T_{i}}=\left[\frac{Y *}{Y}\right]^{\alpha_{i}}, \quad \frac{G *}{G}=\left[\frac{Y *}{Y}\right]^{\beta}
$$

where: $T_{i}=$ actual tax revenues for the ith category of tax

$\mathrm{G}=$ actual government expenditures (excluding capital spending)

$\mathrm{Y}=$ level of actual output

$\mathrm{Y}^{*}=$ level of potential output

$\alpha_{i}=$ elasticity of ith tax category with respect to output

$\beta=$ elasticity of current government expenditures with respect to output

From these relationships, the structural budget balance can be derived as follows:

$$
B *=\sum_{i=1}^{4} T_{i}\left[\frac{Y *}{Y}\right]^{\alpha_{i}}-G\left[\frac{Y *}{Y}\right]^{\beta}+\text { capital spending } \quad \alpha_{i}>0 \quad \beta<0 .
$$

34. The split between estimated cyclical and structural components is relatively sensitive to the estimated output gaps. Typically, if the estimated output gap were 1 percentage point of GDP smaller, the estimated structural component of the actual budget balance would be larger by around 1/2 percentage point 
of GDP. Estimates of the impact of economic activity on budget balances also indicate that tax revenue adjustments far outweigh the effect of expenditure adjustments, which make up only about 10 to 20 per cent of the adjustment. This is because almost all taxes are affected by economic fluctuation, whereas a much smaller proportion of expenditure is devoted to dealing with unemployment and of that, only a portion is cyclical.

\section{Tax elasticities}

35. The Secretariat method makes adjustments to four separate categories of taxes in calculating structural budget balances: corporate taxes, personal income taxes, social security contributions (employers and employees), and indirect taxes. The tax elasticities previously used by the Secretariat have been derived from various sources and while some have been updated on an ad hoc basis over the years, some are now out of date, because of tax reforms that have taken place.

36. One approach would be to calculate elasticities using a simple regression of taxes on output (in current prices). The results of this approach, estimated using data from 1960 to 1992 are shown in Table 3. However, these regressions show the average elasticity over the whole period rather than the current elasticity and embody policy changes in addition to "automatic" effects.

37. For household income tax and social security contributions, new elasticities have been estimated, drawing on data available from various parts of the Secretariat. Average and marginal income tax and social security contribution rates applying to each level of income (and different family circumstance) have been compiled on a systematic basis by the Fiscal Affairs Division of the OECD Secretariat. Weighted averages of these average and marginal tax rates have been calculated using weights derived from income distributions estimated from data provided in the Employment Outlook. The ratio between marginal tax and average tax provides the elasticity with respect to gross earnings. This elasticity is then converted to a GDP elasticity, allowing for cross-country variation in the responsiveness of employment and wages to fluctuations in real output (see Annex 1 for details). The new personal income tax elasticities show much greater variability across countries, while the new social security elasticities are generally higher than the previous elasticities.

38. For corporate taxes and indirect taxes, it has proved more difficult to find reliable alternative methods for estimating them. For corporate taxes, it has been decided to maintain the existing elasticities in the meantime, even though these elasticities do not incorporate up-to-date information on current corporate-tax regimes. For indirect taxes, the previously used elasticities that were used were also quite out of date and it was considered that an assumption of unit elasticity was more appropriate than continuing to the earlier ones. The set of elasticities previously used and the new set of elasticities are shown in Table 4.

\section{Expenditure elasticities}

39. Until now, the adjustment of expenditure for the effects of the cycle has used an average elasticity of -0.2 for all countries, estimated using the Okun elasticities method described below, for lack of additional data. New expenditure elasticities have been estimated for each country, based on the elasticity of the unemployment rate with respect to output (which is the reciprocal of the Okun coefficient), multiplied by the elasticity of unemployment benefits with respect to unemployment. This provides an elasticity of unemployment benefits with respect to output, that can then be applied to all current government expenditure as shown in Table 5. While it would be preferable to adjust unemployment benefit expenditure directly (and any other cyclical components of government expenditure), up-to-date data on unemployment 
benefit expenditure are not readily available. In any case, even with significant increases in unemployment, these expenditures remain a small part of total government expenditures, as shown in Table 6 .

\section{Structural budget balances: results}

40. Adjusted budget balances calculated using the previous (split time trend) method, and the new (potential output) method are presented in Table 7 and shown in Figure 2, using the previous and the revised tax and expenditure elasticities. As noted above, it is clear that the revision of elasticities does not play a major role in explaining the differences in structural budget balances, compared with structural balances previously published by the Secretariat. Instead, where there are major differences, these largely mirror the revision in output gaps.

41. Structural deficits for almost all countries except the United States have been revised significantly. Among the seven major countries, Germany and the United Kingdom's structural deficit positions now look better than previously projected, reflecting larger negative output gaps than under the previous method. For Japan, France, Italy and Canada, structural deficits are significantly larger than previously estimated. For Italy, between 1993 and 1996 the structural deficit, as calculated using the new method, is on average 2 percentage points larger than with the previous method. Taking the period from 1993 to 1996, the path of consolidation also shows some differences for some countries (see Table 8). During that period, Japan is projected to have eased its fiscal stance by more than was estimated using the previous method, and with the new method, France, Italy and Canada are projected to achieve less consolidation than previously estimated.

42. Among the smaller countries, structural deficits for Belgium, Finland, Ireland and the Netherlands are projected to be significantly smaller than under the previous method. For all these countries, output gaps are larger than previously estimated. For Finland, the previous method showed a deteriorating structural deficit position between 1993 and 1996, whereas the new method indicates some consolidation. Spain on the other hand, is now estimated to achieve less consolidation than projected using the previous method.

43. In general, the cyclical part of budget balances, calculated with the new (potential output) method, should tend to balance out over time as accumulations of debt due to cyclical deficits should be offset by cyclical surpluses although this will depend on the symmetry properties of the output gap measure, as discussed earlier. Therefore, it would also be possible for cyclical deficits or surpluses to persist for quite long periods of time. The cyclical component of budget balances (as a per cent of potential GDP) calculated with the new method and the new set of elasticities is shown in Table 9.

\section{Conclusions}

44. The analysis presented in this paper suggests that the Secretariat's previous method used for measuring the output gap by applying split time trend analysis to GDP -- and using it as an input to the construction of its structural budget balances -- was subject to a number of serious shortcomings. In particular it took little or no account of the actual timing of changes in structural factors that affect productive potential and was difficult to estimate and project for the current period and the near future which are most relevant for policy making. 
45. A review of the strengths and weaknesses of alternative methods suggests that a consistent approach should be used for both conjunctural and fiscal assessments, one which is behavioural and represents a potential rate of growth which is sustainable at a stable rate of inflation. The preferred measure is therefore one based on a production function approach and which takes explicit account of structural information, in particular with respect to the NAWRU and the "speed-limits" to growth.

46. Although it is recognised that all output gap measures are subject to considerable uncertainty, a key result arising from the comparisons of the measures considered is that the Secretariat's previous split time trend measure has tended to overestimate the output gaps for the present and immediate future for some countries and underestimate the gaps for others. This has important consequences for the assessment of fiscal positions. The resulting estimated structural budget balances must, however, be interpreted with great caution as they are surrounded by a considerable margin of uncertainty, particularly in economies undergoing substantial restructuring. 
Data up to end-1990 are for western Germany only; unless otherwise indicated, they are for the whole of Germany from 1991 onwards. In tables showing percentage changes from the previous year, data refer to the whole of Germany from 1992 onwards. 
Table 1. Contributions to growth in business sector potential output and NAWRUs

\begin{tabular}{|c|c|c|c|c|c|c|c|}
\hline & $\begin{array}{l}\text { Business sector } \\
\text { potential output }\end{array}$ & $\begin{array}{l}\text { Employment } \\
\text { contribution }\end{array}$ & Trend hours & $\begin{array}{c}\text { Capital } \\
\text { contribution }\end{array}$ & Trend TFP & NAWRU & $\begin{array}{c}\text { Actual } \\
\text { unemployment }\end{array}$ \\
\hline \multicolumn{8}{|l|}{ United States } \\
\hline 1986 & 2.9 & 1.4 & -0.1 & 1.0 & 0.6 & 6.2 & 7.0 \\
\hline 1987 & 2.6 & 1.2 & -0.1 & 0.9 & 0.6 & 5.9 & 6.2 \\
\hline 1988 & 2.4 & 1.0 & 0.0 & 0.9 & 0.6 & 5.7 & 5.5 \\
\hline 1989 & 2.0 & 0.5 & 0.0 & 0.9 & 0.6 & 5.8 & 5.3 \\
\hline 1990 & 1.9 & 0.5 & 0.0 & 0.8 & 0.6 & 5.8 & 5.5 \\
\hline 1991 & 2.4 & 1.0 & 0.1 & 0.7 & 0.6 & 5.8 & 6.7 \\
\hline 1992 & 2.3 & 0.9 & 0.1 & 0.6 & 0.7 & 6.0 & 7.4 \\
\hline 1993 & 2.4 & 0.9 & 0.1 & 0.7 & 0.7 & 6.1 & 6.8 \\
\hline 1994 & 2.7 & 0.9 & 0.1 & 0.9 & 0.7 & 6.2 & 6.1 \\
\hline 1995 & 2.8 & 0.8 & 0.1 & 1.0 & 0.8 & 6.2 & 5.6 \\
\hline 1996 & 2.7 & 0.8 & 0.1 & 1.1 & 0.8 & 6.2 & 5.6 \\
\hline \multicolumn{8}{|c|}{ Germany (Western) } \\
\hline 1986 & 1.8 & -0.1 & -0.5 & 0.8 & 1.6 & 7.3 & 7.7 \\
\hline 1987 & 2.1 & 0.0 & -0.5 & 0.8 & 1.7 & 7.3 & 7.6 \\
\hline 1988 & 2.6 & 0.4 & -0.5 & 0.9 & 1.8 & 7.2 & 7.6 \\
\hline 1989 & 3.1 & 0.8 & -0.5 & 0.9 & 1.9 & 7.0 & 6.9 \\
\hline 1990 & 3.9 & 1.4 & -0.5 & 1.0 & 1.9 & 6.9 & 6.2 \\
\hline 1991 & 3.5 & 0.9 & -0.5 & 1.2 & 1.9 & 6.8 & 5.5 \\
\hline 1992 & 3.4 & 0.9 & -0.5 & 1.1 & 1.8 & 6.9 & 5.8 \\
\hline 1993 & 2.7 & 0.5 & -0.4 & 0.8 & 1.7 & 7.0 & 7.3 \\
\hline 1994 & 2.5 & 0.4 & -0.4 & 0.7 & 1.7 & 7.1 & 8.2 \\
\hline 1995 & 2.4 & 0.3 & -0.4 & 0.7 & 1.7 & 7.2 & 7.9 \\
\hline 1996 & 2.4 & 0.2 & -0.4 & 0.8 & 1.7 & 7.3 & 7.5 \\
\hline \multicolumn{8}{|l|}{ France } \\
\hline 1986 & 2.3 & -0.1 & 0.0 & 0.8 & 1.7 & 8.9 & 10.4 \\
\hline 1987 & 2.7 & 0.2 & 0.0 & 0.8 & 1.6 & 9.0 & 10.5 \\
\hline 1988 & 2.9 & 0.3 & 0.0 & 0.9 & 1.6 & 9.0 & 10.0 \\
\hline 1989 & 3.0 & 0.4 & 0.0 & 1.0 & 1.5 & 9.0 & 9.4 \\
\hline 1990 & 2.7 & 0.1 & 0.0 & 1.1 & 1.5 & 9.1 & 8.9 \\
\hline 1991 & 2.4 & 0.0 & 0.0 & 1.0 & 1.4 & 9.1 & 9.5 \\
\hline 1992 & 2.1 & -0.2 & 0.0 & 0.9 & 1.4 & 9.2 & 10.4 \\
\hline 1993 & 1.8 & -0.3 & 0.0 & 0.7 & 1.4 & 9.2 & 11.7 \\
\hline 1994 & 2.2 & 0.2 & 0.0 & 0.6 & 1.4 & 9.2 & 12.6 \\
\hline 1995 & 2.3 & 0.3 & 0.0 & 0.6 & 1.4 & 9.2 & 12.3 \\
\hline 1996 & 2.4 & 0.3 & 0.0 & 0.7 & 1.4 & 9.2 & 11.7 \\
\hline \multicolumn{8}{|l|}{ Italy } \\
\hline 1986 & 2.0 & 0.0 & .. & 0.7 & 1.3 & 10.4 & 11.2 \\
\hline 1987 & 1.6 & -0.5 &.. & 0.8 & 1.4 & 10.7 & 12.1 \\
\hline 1988 & 2.7 & 0.4 & .. & 0.9 & 1.4 & 11.0 & 12.1 \\
\hline 1989 & 1.9 & -0.5 & .. & 0.9 & 1.4 & 11.0 & 12.1 \\
\hline 1990 & 2.7 & 0.3 & .. & 1.0 & 1.4 & 11.0 & 11.5 \\
\hline 1991 & 2.5 & 0.1 &.. & 0.9 & 1.5 & 11.0 & 11.0 \\
\hline 1992 & 2.6 & 0.3 &.. & 0.8 & 1.5 & 10.8 & 11.6 \\
\hline 1993 & 2.4 & 0.3 &.. & 0.5 & 1.6 & 10.5 & 10.4 \\
\hline 1994 & 2.2 & 0.2 &.. & 0.4 & 1.7 & 10.2 & 11.3 \\
\hline 1995 & 2.4 & 0.2 &.. & 0.4 & 1.7 & 9.8 & 11.2 \\
\hline 1996 & 2.5 & 0.2 &.. & 0.5 & 1.8 & 9.5 & 11.0 \\
\hline
\end{tabular}


Table 1. (Continued)

\begin{tabular}{|c|c|c|c|c|c|c|}
\hline & $\begin{array}{l}\text { Business sector } \\
\text { potential output }\end{array}$ & $\begin{array}{l}\text { Employment } \\
\text { contribution }\end{array}$ & $\begin{array}{c}\text { Capital } \\
\text { contribution }\end{array}$ & Trend TFP & NAWRU & $\begin{array}{c}\text { Actual } \\
\text { unemployment }\end{array}$ \\
\hline \multicolumn{7}{|l|}{ United Kingdom } \\
\hline 1986 & 2.7 & 0.3 & 0.6 & 1.9 & 10.2 & 11.0 \\
\hline 1987 & 2.8 & 0.3 & 0.6 & 1.8 & 9.8 & 9.8 \\
\hline 1988 & 3.1 & 0.6 & 0.8 & 1.7 & 9.3 & 7.8 \\
\hline 1989 & 3.5 & 0.9 & 0.9 & 1.6 & 8.8 & 6.1 \\
\hline 1990 & 3.0 & 0.6 & 0.7 & 1.6 & 8.4 & 5.9 \\
\hline 1991 & 3.5 & 1.4 & 0.4 & 1.6 & 8.2 & 8.2 \\
\hline 1992 & 3.1 & 1.2 & 0.3 & 1.7 & 8.0 & 9.9 \\
\hline 1993 & 2.3 & 0.3 & 0.2 & 1.7 & 7.8 & 10.2 \\
\hline 1994 & 2.3 & 0.3 & 0.2 & 1.8 & 7.7 & 9.4 \\
\hline 1995 & 2.5 & 0.4 & 0.3 & 1.8 & 7.6 & 8.7 \\
\hline 1996 & 2.6 & 0.4 & 0.4 & 1.9 & 7.5 & 7.9 \\
\hline \multicolumn{7}{|l|}{ Canada } \\
\hline 1986 & 2.6 & 0.9 & 1.3 & 0.4 & 9.0 & 9.5 \\
\hline 1987 & 2.4 & 0.8 & 1.4 & 0.3 & 9.0 & 8.8 \\
\hline 1988 & 3.1 & 1.1 & 1.7 & 0.3 & 9.0 & 7.8 \\
\hline 1989 & 3.1 & 1.1 & 1.8 & 0.2 & 9.0 & 7.5 \\
\hline 1990 & 3.0 & 1.2 & 1.6 & 0.2 & 9.0 & 8.1 \\
\hline 1991 & 2.6 & 1.0 & 1.4 & 0.2 & 8.8 & 10.3 \\
\hline 1992 & 2.0 & 0.6 & 1.1 & 0.3 & 8.6 & 11.3 \\
\hline 1993 & 1.8 & 0.5 & 0.9 & 0.4 & 8.5 & 11.2 \\
\hline 1994 & 2.7 & 1.2 & 1.0 & 0.5 & 8.5 & 10.5 \\
\hline 1995 & 2.9 & 1.3 & 1.1 & 0.5 & 8.5 & 9.7 \\
\hline 1996 & 3.0 & 1.3 & 1.2 & 0.6 & 8.5 & 9.2 \\
\hline \multicolumn{7}{|l|}{ Australia } \\
\hline 1986 & 3.3 & 1.2 & 1.2 & 0.9 & 7.9 & 8.0 \\
\hline 1987 & 3.5 & 1.4 & 1.2 & 0.9 & 7.9 & 8.0 \\
\hline 1988 & 3.7 & 1.5 & 1.3 & 0.9 & 8.0 & 7.1 \\
\hline 1989 & 4.3 & 1.9 & 1.5 & 0.9 & 8.1 & 6.1 \\
\hline 1990 & 3.2 & 1.0 & 1.2 & 0.9 & 8.3 & 7.0 \\
\hline 1991 & 2.8 & 1.0 & 0.8 & 0.9 & 8.1 & 9.5 \\
\hline 1992 & 3.3 & 1.6 & 0.7 & 0.9 & 8.0 & 10.7 \\
\hline 1993 & 2.9 & 1.3 & 0.6 & 1.0 & 7.9 & 10.9 \\
\hline 1994 & 2.9 & 1.2 & 0.7 & 1.0 & 7.8 & 9.7 \\
\hline 1995 & 3.2 & 1.3 & 0.9 & 1.0 & 7.7 & 8.7 \\
\hline 1996 & 3.4 & 1.3 & 1.0 & 1.0 & 7.6 & 7.9 \\
\hline \multicolumn{7}{|l|}{ Austria } \\
\hline 1986 & 1.1 & -0.8 & 1.1 & 0.9 & 3.4 & 3.1 \\
\hline 1987 & 1.9 & 0.0 & 1.1 & 0.9 & 3.5 & 3.8 \\
\hline 1988 & 1.9 & -0.1 & 1.2 & 0.8 & 3.5 & 3.6 \\
\hline 1989 & 2.0 & 0.0 & 1.2 & 0.8 & 3.5 & 3.1 \\
\hline 1990 & 3.6 & 1.4 & 1.3 & 0.8 & 3.5 & 3.2 \\
\hline 1991 & 2.8 & 0.7 & 1.3 & 0.8 & 3.5 & 3.5 \\
\hline 1992 & 2.3 & 0.3 & 1.2 & 0.8 & 3.5 & 3.6 \\
\hline 1993 & 2.3 & 0.5 & 1.0 & 0.8 & 3.7 & 4.2 \\
\hline 1994 & 2.2 & 0.4 & 1.1 & 0.8 & 3.9 & 4.4 \\
\hline 1995 & 2.4 & 0.5 & 1.1 & 0.8 & 4.0 & 4.2 \\
\hline 1996 & 2.6 & 0.7 & 1.2 & 0.8 & 4.0 & 4.1 \\
\hline
\end{tabular}


Table 1. (Continued)

\begin{tabular}{|c|c|c|c|c|c|c|}
\hline & $\begin{array}{l}\text { Business sector } \\
\text { potential output }\end{array}$ & $\begin{array}{l}\text { Employment } \\
\text { contribution }\end{array}$ & $\begin{array}{c}\text { Capital } \\
\text { contribution }\end{array}$ & Trend TFP & NAWRU & $\begin{array}{c}\text { Actual } \\
\text { unemployment }\end{array}$ \\
\hline \multicolumn{7}{|l|}{ Belgium } \\
\hline 1986 & 2.0 & -0.1 & 0.7 & 1.3 & 11.7 & 11.6 \\
\hline 1987 & 2.7 & 0.6 & 0.8 & 1.3 & 11.5 & 11.3 \\
\hline 1988 & 2.9 & 0.7 & 0.9 & 1.3 & 11.1 & 10.3 \\
\hline 1989 & 2.8 & 0.4 & 1.1 & 1.2 & 10.9 & 9.3 \\
\hline 1990 & 2.5 & 0.0 & 1.2 & 1.2 & 10.8 & 8.7 \\
\hline 1991 & 2.7 & 0.4 & 1.1 & 1.2 & 10.8 & 9.3 \\
\hline 1992 & 2.5 & 0.3 & 0.9 & 1.2 & 10.8 & 10.3 \\
\hline 1993 & 2.4 & 0.5 & 0.7 & 1.2 & 10.8 & 11.9 \\
\hline 1994 & 2.3 & 0.4 & 0.7 & 1.2 & 10.7 & 12.6 \\
\hline 1995 & 2.6 & 0.6 & 0.8 & 1.2 & 10.5 & 12.1 \\
\hline 1996 & 2.6 & 0.6 & 0.8 & 1.2 & 10.2 & 11.3 \\
\hline \multicolumn{7}{|l|}{ Denmark } \\
\hline 1986 & 3.1 & 0.4 & 1.3 & 1.4 & 8.6 & 7.8 \\
\hline 1987 & 3.0 & 0.4 & 1.1 & 1.4 & 8.7 & 7.8 \\
\hline 1988 & 2.6 & 0.3 & 0.9 & 1.4 & 8.9 & 8.6 \\
\hline 1989 & 2.1 & -0.3 & 1.0 & 1.4 & 9.2 & 9.3 \\
\hline 1990 & 2.6 & 0.2 & 1.0 & 1.5 & 9.6 & 9.6 \\
\hline 1991 & 2.7 & 0.4 & 0.8 & 1.5 & 10.0 & 10.5 \\
\hline 1992 & 2.0 & -0.1 & 0.6 & 1.5 & 10.4 & 11.2 \\
\hline 1993 & 1.4 & -0.7 & 0.6 & 1.5 & 10.4 & 12.2 \\
\hline 1994 & 2.4 & 0.2 & 0.6 & 1.5 & 10.4 & 12.0 \\
\hline 1995 & 2.4 & 0.1 & 0.7 & 1.5 & 10.4 & 10.8 \\
\hline 1996 & 2.6 & 0.3 & 0.8 & 1.5 & 10.4 & 10.1 \\
\hline \multicolumn{7}{|l|}{ Finland } \\
\hline 1986 & 1.6 & -1.5 & 0.9 & 2.2 & 6.8 & 5.4 \\
\hline 1987 & 1.4 & -1.7 & 0.9 & 2.2 & 8.0 & 5.1 \\
\hline 1988 & 1.2 & -1.9 & 0.9 & 2.2 & 9.4 & 4.5 \\
\hline 1989 & 1.6 & -1.8 & 1.2 & 2.2 & 10.8 & 3.5 \\
\hline 1990 & 1.7 & -1.5 & 1.0 & 2.2 & 12.2 & 3.5 \\
\hline 1991 & 1.3 & -1.3 & 0.5 & 2.2 & 13.7 & 7.6 \\
\hline 1992 & 1.4 & -0.9 & 0.1 & 2.2 & 15.2 & 13.1 \\
\hline 1993 & 2.0 & 0.0 & -0.1 & 2.2 & 16.4 & 17.9 \\
\hline 1994 & 3.3 & 1.1 & 0.0 & 2.2 & 16.5 & 18.3 \\
\hline 1995 & 3.2 & 0.9 & 0.1 & 2.2 & 16.3 & 16.3 \\
\hline 1996 & 3.1 & 0.6 & 0.3 & 2.2 & 15.8 & 14.6 \\
\hline \multicolumn{7}{|l|}{ Greece } \\
\hline 1986 & 1.3 & 0.1 & 0.9 & 0.2 & 6.7 & 7.4 \\
\hline 1987 & 1.0 & 0.1 & 0.7 & 0.2 & 7.0 & 7.4 \\
\hline 1988 & 1.2 & 0.1 & 0.8 & 0.2 & 7.3 & 7.7 \\
\hline 1989 & 1.4 & 0.1 & 1.2 & 0.2 & 7.5 & 7.5 \\
\hline 1990 & 1.9 & 0.6 & 1.1 & 0.2 & 7.7 & 7.0 \\
\hline 1991 & 1.5 & 0.4 & 0.9 & 0.2 & 7.9 & 7.7 \\
\hline 1992 & 1.5 & 0.4 & 0.9 & 0.2 & 8.1 & 8.7 \\
\hline 1993 & 1.3 & 0.4 & 0.7 & 0.2 & 8.1 & 8.2 \\
\hline 1994 & 1.5 & 0.3 & 0.9 & 0.3 & 8.1 & 9.7 \\
\hline 1995 & 1.6 & 0.4 & 0.9 & 0.3 & 8.0 & 10.0 \\
\hline 1996 & 1.6 & 0.4 & 0.9 & 0.3 & 8.0 & 10.2 \\
\hline
\end{tabular}


Table 1. (Continued)

\begin{tabular}{|c|c|c|c|c|c|c|}
\hline & $\begin{array}{l}\text { Business sector } \\
\text { potential output }\end{array}$ & $\begin{array}{l}\text { Employment } \\
\text { contribution }\end{array}$ & $\begin{array}{c}\text { Capital } \\
\text { contribution }\end{array}$ & Trend TFP & NAWRU & $\begin{array}{c}\text { Actual } \\
\text { unemployment }\end{array}$ \\
\hline \multicolumn{7}{|l|}{ Ireland } \\
\hline 1986 & 3.3 & -0.3 & 0.4 & 3.2 & 16.9 & 17.4 \\
\hline 1987 & 3.9 & 0.2 & 0.5 & 3.2 & 17.4 & 17.5 \\
\hline 1988 & 4.8 & 1.0 & 0.6 & 3.3 & 17.7 & 16.7 \\
\hline 1989 & 6.1 & 2.1 & 0.7 & 3.3 & 17.2 & 15.6 \\
\hline 1990 & 5.6 & 1.5 & 0.8 & 3.3 & 16.6 & 13.7 \\
\hline 1991 & 5.0 & 1.1 & 0.6 & 3.3 & 16.1 & 15.7 \\
\hline 1992 & 4.9 & 1.1 & 0.5 & 3.3 & 15.7 & 16.3 \\
\hline 1993 & 4.6 & 0.9 & 0.4 & 3.3 & 15.4 & 16.7 \\
\hline 1994 & 4.9 & 1.1 & 0.4 & 3.3 & 14.8 & 15.8 \\
\hline 1995 & 4.4 & 0.5 & 0.5 & 3.3 & 14.8 & 15.3 \\
\hline 1996 & 4.4 & 0.5 & 0.5 & 3.3 & 14.8 & 14.7 \\
\hline
\end{tabular}

Netherlands

$\begin{array}{lllllll}1986 & 2.7 & 0.7 & 0.9 & 1.1 & 9.2 & 9.9 \\ 1987 & 2.6 & 0.7 & 0.8 & 1.1 & 9.3 & 9.6 \\ 1988 & 2.7 & 0.8 & 0.8 & 1.1 & 9.3 & 9.2 \\ 1989 & 2.6 & 0.6 & 0.9 & 1.1 & 9.3 & 8.3 \\ 1990 & 2.7 & 0.6 & 1.0 & 1.1 & 9.3 & 7.5 \\ 1991 & 2.8 & 0.7 & 1.0 & 1.1 & 9.3 & 7.0 \\ 1992 & 2.7 & 0.7 & 0.9 & 1.0 & 9.2 & 6.7 \\ 1993 & 2.4 & 0.6 & 0.8 & 1.0 & 9.1 & 8.3 \\ 1994 & 2.4 & 0.6 & 0.8 & 1.0 & 8.9 & 9.3 \\ 1995 & 2.5 & 0.6 & 0.8 & 1.0 & 8.7 & 8.6 \\ 1996 & 2.5 & 0.5 & 0.9 & 1.0 & 8.5 & 7.9\end{array}$

Norway (Mainland)

$\begin{array}{ll}1986 & 2.2 \\ 1987 & 1.8 \\ 1988 & 1.6 \\ 1989 & 0.5 \\ 1990 & 0.2 \\ 1991 & 0.4 \\ 1992 & 0.8 \\ 1993 & 1.2 \\ 1994 & 1.2 \\ 1995 & 2.0 \\ 1996 & 2.2\end{array}$

$\begin{array}{ll}0.7 & 1.0\end{array}$

0.9

0.4

0.3

$-0.6$

$-0.8$

$-0.6$

$-0.3$

0.1

0.0

0.7

0.9

0.7

0.4

0.4

0.3

0.3

0.3

0.4

0.4

0.5

$\begin{array}{lll}0.5 & 3.1 & 2.0 \\ 0.5 & 3.3 & 2.1 \\ 0.6 & 3.7 & 3.2 \\ 0.6 & 4.1 & 4.9 \\ 0.6 & 4.5 & 5.2 \\ 0.7 & 4.9 & 5.5 \\ 0.7 & 5.2 & 5.9 \\ 0.8 & 5.3 & 6.0 \\ 0.8 & 5.4 & 5.5 \\ 0.8 & 5.3 & 5.2 \\ 0.8 & 5.1 & 4.8\end{array}$

Spain

$\begin{array}{ll}1986 & 1.4 \\ 1987 & 2.7 \\ 1988 & 3.1 \\ 1989 & 2.8 \\ 1990 & 2.9 \\ 1991 & 2.9 \\ 1992 & 2.8 \\ 1993 & 2.3 \\ 1994 & 2.1 \\ 1995 & 3.0 \\ 1996 & 3.1\end{array}$

$\begin{array}{rrrrr}-0.8 & 0.7 & 1.5 & 19.1 & 21.0 \\ 0.1 & 1.1 & 1.5 & 19.4 & 20.5 \\ 0.3 & 1.3 & 1.5 & 19.5 & 19.5 \\ -0.3 & 1.6 & 1.5 & 19.6 & 17.3 \\ -0.2 & 1.6 & 1.5 & 19.8 & 16.3 \\ -0.1 & 1.5 & 1.5 & 20.0 & 16.3 \\ 0.1 & 1.3 & 1.5 & 20.3 & 18.4 \\ 0.0 & 0.8 & 1.5 & 20.7 & 22.7 \\ 0.0 & 0.6 & 1.5 & 21.0 & 24.3 \\ 0.9 & 0.7 & 1.5 & 20.5 & 24.0 \\ 0.9 & 0.7 & 1.5 & 20.0 & 23.4\end{array}$


Table 1. (Continued)

\begin{tabular}{|c|c|c|c|c|c|c|}
\hline & $\begin{array}{l}\text { Business sector } \\
\text { potential output }\end{array}$ & $\begin{array}{l}\text { Employment } \\
\text { contribution }\end{array}$ & $\begin{array}{c}\text { Capital } \\
\text { contribution }\end{array}$ & Trend TFP & NAWRU & $\begin{array}{c}\text { Actual } \\
\text { unemployment }\end{array}$ \\
\hline \multicolumn{7}{|l|}{ Sweden } \\
\hline 1986 & 2.3 & 0.5 & 0.9 & 1.0 & 2.1 & 2.2 \\
\hline 1987 & 2.8 & 0.8 & 1.0 & 1.0 & 2.1 & 1.9 \\
\hline 1988 & 2.0 & 0.0 & 1.0 & 1.0 & 2.3 & 1.6 \\
\hline 1989 & 1.9 & -0.4 & 1.2 & 1.1 & 2.6 & 1.4 \\
\hline 1990 & 0.4 & -1.9 & 1.2 & 1.1 & 3.2 & 1.5 \\
\hline 1991 & 1.9 & -0.1 & 0.8 & 1.2 & 3.9 & 2.7 \\
\hline 1992 & 2.2 & 0.5 & 0.5 & 1.2 & 4.8 & 4.8 \\
\hline 1993 & 1.9 & 0.4 & 0.2 & 1.2 & 5.6 & 8.3 \\
\hline 1994 & 2.1 & 0.5 & 0.4 & 1.3 & 6.3 & 7.9 \\
\hline 1995 & 2.0 & 0.4 & 0.3 & 1.3 & 6.5 & 7.8 \\
\hline 1996 & 2.0 & 0.3 & 0.4 & 1.3 & 6.5 & 7.5 \\
\hline
\end{tabular}

\begin{tabular}{cccccccc}
\hline & $\begin{array}{c}\text { Business sector } \\
\text { output potential }\end{array}$ & $\begin{array}{c}\text { Potential } \\
\text { employment }\end{array}$ & $\begin{array}{c}\text { Trend } \\
\text { hours }\end{array}$ & $\begin{array}{c}\text { Capital } \\
\text { stock }\end{array}$ & $\begin{array}{c}\text { Trend labour } \\
\text { efficiency }\end{array}$ & NAWRU & $\begin{array}{c}\text { Actual } \\
\text { unemployment }\end{array}$ \\
\hline Japan $^{\mathbf{a}}{ }^{2}$ & & & & & & & \\
\\
1986 & 4.8 & 1.6 & 0.1 & 5.5 & 2.8 & 2.1 & 2.8 \\
& & 1.2 & 0.1 & 5.1 & 2.9 & 2.3 & 2.9 \\
1987 & 4.4 & 1.7 & -1.5 & 5.4 & 2.9 & 2.2 & 2.5 \\
1988 & 3.6 & 1.5 & -1.5 & 6.3 & 2.9 & 2.3 & 2.3 \\
1989 & 3.6 & 1.0 & -1.5 & 6.9 & 2.9 & 2.2 & 2.1 \\
1990 & 3.3 & 1.0 & -1.5 & 7.0 & 2.9 & 2.2 & 2.1 \\
1991 & 3.2 & 0.6 & -1.5 & 6.2 & 2.5 & 2.2 & 2.2 \\
1993 & 2.4 & 1.0 & -1.5 & 5.0 & 2.4 & 2.2 & 2.5 \\
1994 & 2.4 & 1.2 & -0.2 & 3.8 & 2.4 & 2.2 & 2.9 \\
1995 & 3.5 & 1.2 & -0.3 & 3.5 & 2.4 & 2.2 & 3.0 \\
1996 & 3.3 & 1.2 & -0.3 & 3.4 & 2.4 & 2.2 & 2.9 \\
\hline
\end{tabular}

a) Given that a CES production function is used for Japan, a comparable decomposition of potential is not available. The reported series are however, the most influential factors involved. 
Table 2. Growth rates and output gaps under different methods

\begin{tabular}{|c|c|c|c|c|c|c|c|}
\hline & \multicolumn{4}{|c|}{ Growth rates } & \multicolumn{3}{|c|}{ Output gaps } \\
\hline & Actual & Previous method & Hodrick-Prescott & Potential & Previous method & Hodrick-Prescott & Potential \\
\hline \multicolumn{8}{|l|}{ United States } \\
\hline 1987 & 3.1 & 2.6 & 2.9 & 2.5 & 1.0 & 0.7 & 0.2 \\
\hline 1988 & 3.9 & 2.6 & 2.7 & 2.4 & 2.3 & 1.9 & 1.7 \\
\hline 1989 & 2.5 & 2.4 & 2.5 & 2.0 & 2.5 & 1.9 & 2.2 \\
\hline 1990 & 1.2 & 2.3 & 2.3 & 2.1 & 1.4 & 0.9 & 1.4 \\
\hline 1991 & -0.6 & 2.2 & 2.2 & 2.2 & -1.4 & -1.9 & -1.4 \\
\hline 1992 & 2.3 & 2.2 & 2.2 & 2.2 & -1.3 & -1.8 & -1.3 \\
\hline 1993 & 3.1 & 2.3 & 2.3 & 2.3 & -0.5 & -1.1 & -0.4 \\
\hline 1994 & 3.9 & 2.4 & 2.4 & 2.5 & 1.0 & 0.4 & 1.0 \\
\hline 1995 & 3.1 & 2.4 & 2.4 & 2.5 & 1.6 & 1.0 & 1.5 \\
\hline 1996 & 2.0 & 2.4 & 2.4 & 2.5 & 1.2 & 0.6 & 1.0 \\
\hline \multicolumn{8}{|l|}{ Japan } \\
\hline 1987 & 4.1 & 4.1 & 4.2 & 4.1 & -1.9 & -1.5 & -3.8 \\
\hline 1988 & 6.2 & 4.1 & 4.2 & 3.4 & 0.1 & 0.4 & -1.2 \\
\hline 1989 & 4.7 & 4.1 & 4.0 & 3.3 & 0.7 & 1.1 & 0.1 \\
\hline 1990 & 4.8 & 4.0 & 3.6 & 3.2 & 1.5 & 2.3 & 1.8 \\
\hline 1991 & 4.3 & 3.8 & 3.2 & 2.9 & 1.9 & 3.4 & 3.1 \\
\hline 1992 & 1.1 & 3.6 & 2.8 & 2.3 & -0.5 & 1.8 & 2.0 \\
\hline 1993 & 0.1 & 3.5 & 2.5 & 2.2 & -3.8 & -0.6 & -0.2 \\
\hline 1994 & 1.0 & 3.4 & 2.4 & 3.2 & -6.0 & -2.0 & -2.3 \\
\hline 1995 & 2.5 & 3.4 & 2.5 & 3.0 & -6.9 & -2.0 & -2.8 \\
\hline 1996 & 3.4 & 3.4 & 2.7 & 3.0 & -6.9 & -1.3 & -2.5 \\
\hline \multicolumn{8}{|l|}{ Germany } \\
\hline 1987 & 1.5 & 2.2 & 2.7 & 2.0 & -2.8 & -1.9 & -1.8 \\
\hline 1988 & 3.7 & 2.2 & 3.0 & 2.4 & -1.3 & -1.2 & -0.5 \\
\hline 1989 & 3.6 & 2.2 & 3.1 & 2.8 & 0.1 & -0.7 & 0.2 \\
\hline 1990 & 5.7 & 2.6 & 3.1 & 3.6 & 3.1 & 1.7 & 2.3 \\
\hline 1991 & 5.0 & 2.6 & 3.0 & 3.2 & 5.1 & 3.5 & 3.8 \\
\hline 1992 & 2.2 & 3.0 & 3.0 & 3.5 & 4.3 & 2.7 & 2.5 \\
\hline 1993 & -1.1 & 2.9 & 2.6 & 2.6 & 0.3 & -1.1 & -1.2 \\
\hline 1994 & 2.8 & 2.8 & 2.8 & 2.8 & 0.3 & -1.1 & -1.2 \\
\hline 1995 & 2.8 & 2.6 & 2.8 & 2.8 & 0.6 & -1.0 & -1.1 \\
\hline 1996 & 3.5 & 2.6 & 2.9 & 2.9 & 1.4 & -0.4 & -0.5 \\
\hline \multicolumn{8}{|l|}{ France } \\
\hline 1987 & 2.3 & 2.5 & 2.2 & 2.4 & -3.1 & -1.6 & -2.3 \\
\hline 1988 & 4.5 & 2.5 & 2.2 & 2.6 & -1.2 & 0.6 & -0.5 \\
\hline 1989 & 4.3 & 2.5 & 2.2 & 2.6 & 0.5 & 2.6 & 1.1 \\
\hline 1990 & 2.5 & 2.5 & 2.2 & 2.4 & 0.5 & 3.0 & 1.2 \\
\hline 1991 & 0.8 & 2.5 & 2.1 & 2.2 & -1.1 & 1.6 & -0.2 \\
\hline 1992 & 1.2 & 2.5 & 2.1 & 2.0 & -2.4 & 0.7 & -1.0 \\
\hline 1993 & -1.0 & 2.5 & 2.1 & 1.9 & -5.7 & -2.3 & -3.7 \\
\hline 1994 & 2.2 & 2.5 & 2.2 & 2.0 & -6.0 & -2.3 & -3.5 \\
\hline 1995 & 3.1 & 2.5 & 2.2 & 2.1 & -5.5 & -1.5 & -2.6 \\
\hline 1996 & 3.2 & 2.5 & 2.3 & 2.2 & -4.9 & -0.6 & -1.6 \\
\hline
\end{tabular}


Table 2 (continued)

\begin{tabular}{|c|c|c|c|c|c|c|c|}
\hline & \multicolumn{4}{|c|}{ Growth rates } & \multicolumn{3}{|c|}{ Output gaps } \\
\hline & Actual & Previous method & Hodrick-Prescott & Potential & Previous method & Hodrick-Prescott & Potential \\
\hline \multicolumn{8}{|l|}{ Italy } \\
\hline 1987 & 3.1 & 2.4 & 2.5 & 1.7 & -1.0 & -0.3 & 1.5 \\
\hline 1988 & 4.1 & 2.4 & 2.5 & 2.6 & 0.6 & 1.2 & 2.9 \\
\hline 1989 & 2.9 & 2.4 & 2.3 & 1.8 & 1.2 & 1.8 & 4.0 \\
\hline 1990 & 2.1 & 2.4 & 2.1 & 2.5 & 0.9 & 1.9 & 3.7 \\
\hline 1991 & 1.2 & 2.4 & 1.8 & 2.3 & -0.3 & 1.3 & 2.6 \\
\hline 1992 & 0.7 & 2.4 & 1.7 & 2.5 & -1.9 & 0.3 & 0.8 \\
\hline 1993 & -0.7 & 2.4 & 1.7 & 2.3 & -4.8 & -2.0 & -2.1 \\
\hline 1994 & 2.2 & 2.4 & 1.8 & 2.1 & -5.0 & -1.7 & -2.0 \\
\hline 1995 & 2.7 & 2.4 & 2.0 & 2.0 & -4.8 & -1.0 & -1.4 \\
\hline 1996 & 2.9 & 2.4 & 2.2 & 2.2 & -4.3 & -0.4 & -0.7 \\
\hline \multicolumn{8}{|l|}{ United Kingdom } \\
\hline 1987 & 4.8 & 2.6 & 2.5 & 2.5 & 3.0 & 2.6 & 2.8 \\
\hline 1988 & 5.0 & 2.6 & 2.4 & 2.8 & 5.5 & 5.2 & 5.0 \\
\hline 1989 & 2.2 & 2.6 & 2.3 & 2.7 & 5.1 & 5.1 & 4.6 \\
\hline 1990 & 0.4 & 2.6 & 2.1 & 2.7 & 2.9 & 3.3 & 2.2 \\
\hline 1991 & -2.0 & 2.3 & 2.0 & 2.8 & -1.3 & -0.7 & -2.5 \\
\hline 1992 & -0.5 & 2.3 & 2.0 & 2.3 & -4.0 & -3.2 & -5.1 \\
\hline 1993 & 2.0 & 2.3 & 2.1 & 2.1 & -4.2 & -3.2 & -5.2 \\
\hline 1994 & 3.5 & 2.3 & 2.2 & 2.1 & -3.0 & -2.0 & -3.9 \\
\hline 1995 & 3.4 & 2.3 & 2.3 & 2.3 & -1.9 & -1.0 & -2.9 \\
\hline 1996 & 3.0 & 2.3 & 2.4 & 2.4 & -1.2 & -0.4 & -2.3 \\
\hline \multicolumn{8}{|l|}{ Canada } \\
\hline 1987 & 4.2 & 3.0 & 2.7 & 2.6 & 1.3 & 2.2 & 2.6 \\
\hline 1988 & 5.0 & 3.0 & 2.6 & 3.0 & 3.3 & 4.6 & 4.6 \\
\hline 1989 & 2.4 & 3.0 & 2.5 & 3.0 & 2.7 & 4.6 & 4.0 \\
\hline 1990 & -0.2 & 2.7 & 2.4 & 2.9 & -0.2 & 1.9 & 0.8 \\
\hline 1991 & -1.8 & 2.5 & 2.4 & 2.6 & -4.5 & -2.3 & -3.5 \\
\hline 1992 & 0.6 & 2.5 & 2.4 & 2.0 & -6.2 & -4.0 & -4.8 \\
\hline 1993 & 2.2 & 2.5 & 2.5 & 1.8 & -6.5 & -4.3 & -4.4 \\
\hline 1994 & 4.1 & 2.7 & 2.6 & 2.5 & -5.2 & -2.8 & -2.9 \\
\hline 1995 & 4.2 & 3.0 & 2.7 & 2.9 & -4.2 & -1.4 & -1.7 \\
\hline 1996 & 3.9 & 3.0 & 2.8 & 3.0 & -3.3 & -0.3 & -0.8 \\
\hline \multicolumn{8}{|l|}{ Australia } \\
\hline 1987 & 4.7 & 4.1 & 3.4 & 3.4 & 0.7 & 0.9 & 0.6 \\
\hline 1988 & 4.1 & 4.1 & 3.2 & 3.4 & 0.7 & 1.7 & 1.3 \\
\hline 1989 & 4.5 & 4.1 & 3.0 & 3.6 & 1.1 & 3.3 & 2.2 \\
\hline 1990 & 1.3 & 2.7 & 2.7 & 3.1 & -0.3 & 1.9 & 0.4 \\
\hline 1991 & -1.3 & 2.7 & 2.6 & 2.7 & -4.2 & -2.0 & -3.4 \\
\hline 1992 & 2.1 & 2.7 & 2.7 & 2.8 & -4.8 & -2.6 & -4.1 \\
\hline 1993 & 3.8 & 2.7 & 2.9 & 2.5 & -3.9 & -1.7 & -2.9 \\
\hline 1994 & 4.3 & 2.7 & 3.1 & 2.8 & -2.4 & -0.6 & -1.4 \\
\hline 1995 & 4.3 & 2.7 & 3.3 & 3.0 & -1.0 & 0.3 & -0.2 \\
\hline 1996 & 4.0 & 2.7 & 3.4 & 3.1 & 0.2 & 0.8 & 0.6 \\
\hline
\end{tabular}


Table 2 (continued)

\begin{tabular}{|c|c|c|c|c|c|c|c|}
\hline & \multicolumn{4}{|c|}{ Growth rates } & \multicolumn{3}{|c|}{ Output gaps } \\
\hline & Actual & Previous method & Hodrick-Prescott & Potential & Previous method & Hodrick-Prescott & Potential \\
\hline \multicolumn{8}{|l|}{ Austria } \\
\hline 1987 & 1.7 & 2.2 & 2.4 & 1.9 & -2.3 & -2.0 & -4.3 \\
\hline 1988 & 4.1 & 2.2 & 2.6 & 1.9 & -0.6 & -0.6 & -2.3 \\
\hline 1989 & 3.8 & 3.0 & 2.7 & 2.0 & 0.2 & 0.5 & -0.5 \\
\hline 1990 & 4.2 & 3.0 & 2.7 & 2.9 & 1.4 & 2.0 & 0.8 \\
\hline 1991 & 2.7 & 3.0 & 2.6 & 2.8 & 1.2 & 2.1 & 0.7 \\
\hline 1992 & 1.6 & 3.0 & 2.5 & 2.2 & -0.2 & 1.2 & 0.1 \\
\hline 1993 & -0.3 & 2.2 & 2.4 & 2.1 & -2.6 & -1.4 & -2.2 \\
\hline 1994 & 2.6 & 2.2 & 2.4 & 2.1 & -2.2 & -1.2 & -1.7 \\
\hline 1995 & 3.0 & 2.2 & 2.5 & 2.2 & -1.5 & -0.6 & -0.9 \\
\hline 1996 & 3.1 & 2.2 & 2.5 & 2.4 & -0.16 & -0.1 & -0.3 \\
\hline \multicolumn{8}{|l|}{ Belgium } \\
\hline 1987 & 2.0 & 2.0 & 2.3 & 2.2 & -2.7 & -1.9 & -2.5 \\
\hline 1988 & 4.9 & 2.0 & 2.5 & 2.6 & 0.1 & 0.3 & -0.4 \\
\hline 1989 & 3.5 & 2.0 & 2.6 & 2.4 & 1.6 & 1.2 & 0.7 \\
\hline 1990 & 3.2 & 2.0 & 2.5 & 2.3 & 2.8 & 2.0 & 1.6 \\
\hline 1991 & 2.3 & 2.0 & 2.3 & 2.2 & 3.1 & 2.0 & 1.7 \\
\hline 1992 & 1.9 & 2.0 & 2.1 & 2.1 & 3.0 & 1.7 & 1.5 \\
\hline 1993 & -1.7 & 2.0 & 2.0 & 2.1 & -0.7 & -1.9 & -2.3 \\
\hline 1994 & 2.3 & 2.0 & 2.0 & 2.1 & -0.4 & -1.7 & -2.1 \\
\hline 1995 & 3.0 & 2.0 & 2.1 & 2.3 & 0.7 & -0.8 & -1.3 \\
\hline 1996 & 3.1 & 2.0 & 2.3 & 2.4 & 1.8 & 0.0 & -0.7 \\
\hline \multicolumn{8}{|l|}{ Denmark } \\
\hline 1987 & 0.3 & 2.0 & 2.0 & 2.6 & 0.9 & 1.4 & 0.7 \\
\hline 1988 & 1.2 & 2.0 & 1.7 & 2.5 & 0.0 & 0.9 & -0.6 \\
\hline 1989 & 0.6 & 2.0 & 1.6 & 1.7 & -1.4 & -0.2 & -1.7 \\
\hline 1990 & 1.4 & 2.0 & 1.6 & 2.2 & -1.9 & -0.3 & -2.5 \\
\hline 1991 & 1.0 & 2.0 & 1.7 & 2.2 & -2.9 & -1.0 & -3.6 \\
\hline 1992 & 1.2 & 2.0 & 1.9 & 1.8 & -3.6 & -1.6 & -4.1 \\
\hline 1993 & 1.4 & 2.0 & 2.1 & 1.5 & -4.1 & -2.3 & -4.2 \\
\hline 1994 & 4.7 & 2.0 & 2.4 & 2.3 & -1.6 & 0.0 & -1.9 \\
\hline 1995 & 3.3 & 2.0 & 2.6 & 2.1 & -0.3 & 0.6 & -0.8 \\
\hline 1996 & 2.9 & 2.0 & 2.7 & 2.2 & -0.6 & 0.8 & -0.1 \\
\hline \multicolumn{8}{|l|}{ Finland } \\
\hline 1987 & 4.1 & 2.5 & 2.6 & 1.7 & 3.4 & 0.2 & 4.0 \\
\hline 1988 & 4.9 & 2.3 & 2.0 & 1.4 & 6.0 & 3.0 & 7.6 \\
\hline 1989 & 5.7 & 2.0 & 1.3 & 1.6 & 9.9 & 7.4 & 11.9 \\
\hline 1990 & 0.0 & 0.9 & 0.5 & 1.7 & 8.9 & 6.9 & 10.0 \\
\hline 1991 & -7.1 & 0.9 & 0.0 & 1.3 & 0.3 & -0.6 & 0.9 \\
\hline 1992 & -3.6 & 0.9 & -0.1 & 0.8 & -4.2 & -4.2 & -3.5 \\
\hline 1993 & -2.0 & 0.9 & 0.3 & 0.9 & -7.0 & -6.4 & -6.3 \\
\hline 1994 & 3.5 & 0.9 & 1.1 & 2.1 & -4.5 & -4.1 & -5.0 \\
\hline 1995 & 4.8 & 0.9 & 1.8 & 2.2 & -0.8 & -1.3 & -2.5 \\
\hline 1996 & 3.9 & 0.9 & 2.5 & 2.6 & 2.1 & 0.1 & -1.3 \\
\hline
\end{tabular}


Table 2 (continued)

\begin{tabular}{|c|c|c|c|c|c|c|c|}
\hline & \multicolumn{4}{|c|}{ Growth rates } & \multicolumn{3}{|c|}{ Output gaps } \\
\hline & Actual & Previous method & Hodrick-Prescott & Potential & Previous method & Hodrick-Prescott & Potential \\
\hline \multicolumn{8}{|l|}{ Greece } \\
\hline 1987 & -0.5 & 1.7 & 1.8 & 1.0 & -2.1 & -2.2 & -4.1 \\
\hline 1988 & 4.4 & 1.7 & 1.8 & 1.2 & 0.5 & 0.3 & -1.1 \\
\hline 1989 & 4.0 & 1.7 & 1.8 & 1.8 & 2.8 & 2.5 & 1.1 \\
\hline 1990 & -1.0 & 1.7 & 1.6 & 1.6 & 0.1 & -0.1 & -1.4 \\
\hline 1991 & 3.2 & 1.7 & 1.5 & 1.4 & 1.5 & 1.5 & 0.3 \\
\hline 1992 & 0.8 & 1.7 & 1.3 & 1.3 & 0.6 & 1.0 & -0.2 \\
\hline 1993 & -0.5 & 1.7 & 1.3 & 1.2 & -1.6 & -0.8 & -1.9 \\
\hline 1994 & 1.0 & 1.7 & 1.3 & 1.4 & -2.3 & -1.2 & -2.3 \\
\hline 1995 & 1.5 & 1.7 & 1.4 & 1.4 & -2.5 & -1.1 & -2.3 \\
\hline 1996 & 2.3 & 1.7 & 1.6 & 1.5 & -2.0 & -0.5 & -1.5 \\
\hline \multicolumn{8}{|l|}{ Ireland } \\
\hline 1987 & 5.7 & 3.3 & 3.8 & 3.6 & -2.3 & -2.4 & -3.9 \\
\hline 1988 & 4.3 & 4.7 & 4.4 & 4.0 & -2.6 & -2.5 & -3.6 \\
\hline 1989 & 7.4 & 4.7 & 4.8 & 5.1 & -0.1 & -0.1 & -1.6 \\
\hline 1990 & 8.6 & 4.7 & 5.1 & 5.2 & 3.6 & 3.2 & 1.6 \\
\hline 1991 & 2.9 & 4.7 & 5.1 & 4.8 & 1.8 & 1.0 & -0.2 \\
\hline 1992 & 5.0 & 4.7 & 5.1 & 4.7 & 2.2 & 1.0 & 0.1 \\
\hline 1993 & 4.0 & 4.7 & 5.0 & 4.3 & 1.5 & 0.0 & -0.2 \\
\hline 1994 & 5.0 & 4.7 & 4.9 & 4.8 & 1.7 & 0.1 & -0.1 \\
\hline 1995 & 5.0 & 4.7 & 4.8 & 4.3 & 2.0 & 0.2 & 0.6 \\
\hline 1996 & 4.6 & 4.7 & 4.7 & 4.3 & 1.9 & 0.1 & 0.9 \\
\hline \multicolumn{8}{|l|}{ Netherlands } \\
\hline 1987 & 1.2 & 2.2 & 2.4 & 2.5 & -2.1 & -1.0 & -3.5 \\
\hline 1988 & 2.6 & 2.2 & 2.6 & 2.3 & -1.7 & -1.0 & -3.3 \\
\hline 1989 & 4.7 & 2.2 & 2.7 & 2.3 & 0.7 & 0.8 & -1.0 \\
\hline 1990 & 4.1 & 2.2 & 2.7 & 2.4 & 2.6 & 2.2 & 0.7 \\
\hline 1991 & 2.1 & 2.2 & 2.6 & 2.4 & 2.5 & 1.8 & 0.4 \\
\hline 1992 & 1.4 & 2.2 & 2.4 & 2.4 & 1.7 & 0.8 & -0.6 \\
\hline 1993 & 0.4 & 2.2 & 2.4 & 2.2 & -0.1 & -1.2 & -2.3 \\
\hline 1994 & 2.5 & 2.2 & 2.4 & 2.2 & 0.2 & -1.1 & -2.1 \\
\hline 1995 & 2.9 & 2.2 & 2.4 & 2.3 & 0.9 & -0.7 & -1.5 \\
\hline 1996 & 3.2 & 2.2 & 2.5 & 2.4 & 1.9 & 0.0 & -0.7 \\
\hline \multicolumn{8}{|c|}{ Norway, mainland } \\
\hline 1987 & 1.2 & 0.7 & 1.4 & 2.3 & 5.6 & 4.0 & 5.0 \\
\hline 1988 & -1.7 & 1.2 & 0.9 & 1.8 & 2.5 & 1.3 & 1.4 \\
\hline 1989 & -2.2 & 1.8 & 0.6 & 1.3 & -1.5 & -1.6 & -2.1 \\
\hline 1990 & 1.1 & 1.8 & 0.6 & 0.8 & -2.2 & -1.1 & -1.9 \\
\hline 1991 & -0.6 & 1.8 & 0.8 & 1.4 & -4.5 & -2.6 & -3.8 \\
\hline 1992 & 2.1 & 1.8 & 1.2 & 1.6 & -4.3 & -1.7 & -3.3 \\
\hline 1993 & 2.0 & 1.8 & 1.6 & 1.5 & -4.1 & -1.3 & -2.9 \\
\hline 1994 & 3.1 & 1.8 & 1.9 & 2.2 & -2.9 & -0.2 & -2.1 \\
\hline 1995 & 2.7 & 1.8 & 2.2 & 1.9 & -2.0 & 0.4 & -1.3 \\
\hline 1996 & 2.5 & 1.8 & 2.4 & 2.0 & -1.4 & 0.2 & -0.8 \\
\hline
\end{tabular}


Table 2 (continued)

\begin{tabular}{|c|c|c|c|c|c|c|c|}
\hline & \multicolumn{4}{|c|}{ Growth rates } & \multicolumn{3}{|c|}{ Output gaps } \\
\hline & Actual & Previous method & Hodrick-Prescott & Potential & Previous method & Hodrick-Prescott & Potential \\
\hline \multicolumn{8}{|l|}{ Portugal } \\
\hline 1987 & 5.3 & 3.0 & 3.2 & 3.0 & -2.0 & -0.5 & -2.0 \\
\hline 1988 & 3.9 & 3.0 & 3.3 & 3.0 & -1.1 & 0.1 & -1.1 \\
\hline 1989 & 5.2 & 3.0 & 3.2 & 3.0 & 1.0 & 2.0 & 1.0 \\
\hline 1990 & 4.4 & 2.5 & 3.0 & 2.5 & 2.8 & 3.4 & 2.8 \\
\hline 1991 & 2.1 & 2.5 & 2.6 & 2.5 & 2.5 & 3.0 & 2.5 \\
\hline 1992 & 1.1 & 2.5 & 2.2 & 2.5 & 1.1 & 1.8 & 1.1 \\
\hline 1993 & -1.1 & 2.5 & 2.0 & 2.5 & -2.4 & -1.2 & -2.4 \\
\hline 1994 & 1.0 & 2.5 & 2.0 & 2.5 & -3.9 & -2.2 & -3.9 \\
\hline 1995 & 2.6 & 2.5 & 2.1 & 2.5 & -3.8 & -1.7 & -3.8 \\
\hline 1996 & 2.9 & 2.5 & 2.4 & 2.5 & -3.4 & -1.2 & -3.4 \\
\hline \multicolumn{8}{|l|}{ Spain } \\
\hline 1987 & 5.6 & 3.0 & 3.5 & 2.7 & 0.1 & -0.1 & -0.9 \\
\hline 1988 & 5.2 & 3.0 & 3.6 & 3.1 & 2.2 & 1.4 & 1.1 \\
\hline 1989 & 4.7 & 3.0 & 3.4 & 3.4 & 4.0 & 2.7 & 2.5 \\
\hline 1990 & 3.6 & 3.0 & 3.1 & 3.2 & 4.6 & 3.2 & 2.9 \\
\hline 1991 & 2.2 & 3.0 & 2.7 & 3.1 & 3.8 & 2.8 & 2.0 \\
\hline 1992 & 0.8 & 3.0 & 2.3 & 2.8 & 1.6 & 1.3 & 0.0 \\
\hline 1993 & -1.0 & 3.0 & 2.1 & 2.0 & -2.4 & -1.8 & -2.9 \\
\hline 1994 & 1.7 & 3.0 & 2.2 & 2.0 & -3.6 & -2.3 & -3.2 \\
\hline 1995 & 2.9 & 3.0 & 2.4 & 2.7 & -3.7 & -1.8 & -3.0 \\
\hline 1996 & 3.3 & 3.0 & 2.6 & 2.8 & -3.4 & -1.1 & -2.6 \\
\hline \multicolumn{8}{|l|}{ Sweden } \\
\hline 1987 & 3.1 & 1.7 & 2.0 & 2.1 & 4.6 & 0.9 & 3.1 \\
\hline 1988 & 2.3 & 1.7 & 1.7 & 1.8 & 5.2 & 1.5 & 3.6 \\
\hline 1989 & 2.4 & 1.5 & 1.3 & 2.2 & 6.1 & 2.6 & 3.8 \\
\hline 1990 & 1.4 & 1.5 & 0.9 & 0.5 & 5.9 & 3.1 & 4.7 \\
\hline 1991 & -1.1 & 1.3 & 0.6 & 1.6 & 3.4 & 1.6 & 2.0 \\
\hline 1992 & -1.9 & 1.3 & 0.4 & 1.3 & 0.1 & -0.6 & -1.3 \\
\hline 1993 & -2.1 & 1.3 & 0.5 & 1.0 & -3.2 & -2.9 & -4.3 \\
\hline 1994 & 2.3 & 1.3 & 0.9 & 1.3 & -2.2 & -1.9 & -3.9 \\
\hline 1995 & 2.3 & 1.3 & 1.2 & 1.5 & -1.3 & -1.6 & -4.1 \\
\hline 1996 & 2.5 & 1.3 & 1.6 & 1.6 & -2.7 & -1.3 & -4.1 \\
\hline
\end{tabular}


Table 3. Regression-based tax elasticities ${ }^{\mathrm{a}}$

\begin{tabular}{|c|c|c|c|c|}
\hline & Corporate tax & $\begin{array}{l}\text { Household income } \\
\qquad \operatorname{tax}\end{array}$ & $\begin{array}{l}\text { Social security } \\
\text { contributions }\end{array}$ & Indirect taxes \\
\hline United States & 2.3 & 1.3 & 1.0 & 0.4 \\
\hline Japan & 1.4 & 1.1 & 1.0 & 0.9 \\
\hline Germany & 0.8 & 1.8 & 1.2 & 0.8 \\
\hline France & 2.2 & 1.1 & 1.3 & 1.2 \\
\hline Italy & 0.7 & 1.4 & 0.9 & 1.1 \\
\hline United Kingdom & 0.5 & 0.9 & 1.1 & 1.0 \\
\hline Canada & 1.9 & 0.8 & 1.2 & 0.9 \\
\hline Australia & -2.3 & 1.6 & n.a. & 1.2 \\
\hline Austria & 0.4 & 1.5 & 1.0 & 1.2 \\
\hline Belgium & 1.9 & 1.6 & 1.1 & 0.7 \\
\hline Denmark & 1.9 & 0.7 & 0.5 & 1.0 \\
\hline Finland & 1.0 & 1.1 & 0.4 & 0.9 \\
\hline Greece & 0.9 & 1.2 & 0.8 & 0.9 \\
\hline Ireland & 0.4 & 1.1 & 1.3 & 0.9 \\
\hline Netherlands & 0.8 & 1.3 & 1.1 & 0.9 \\
\hline Norway $^{b}$ & 1.2 & 0.7 & 1.2 & 1.1 \\
\hline Portugal & 1.5 & 0.9 & 0.8 & 1.0 \\
\hline Spain & 0.5 & 1.8 & 1.3 & 0.5 \\
\hline Sweden & 0.2 & 1.2 & 1.0 & 1.0 \\
\hline
\end{tabular}

a) Diagnostic statistics available on request. Simple regression of each tax component on output in current dollars.

b) Mainland GDP. 
Table 4. Tax elasticities: previous and new elasticities

\begin{tabular}{|c|c|c|c|c|c|c|c|c|}
\hline & \multicolumn{4}{|c|}{ Previous elasticities } & \multicolumn{4}{|c|}{ New elasticities } \\
\hline & Corporate & Personal & Indirect & $\begin{array}{c}\text { Social } \\
\text { security }\end{array}$ & Corporate & Personal $^{\mathrm{a}}$ & Indirect & $\begin{array}{c}\text { Social } \\
\text { security }^{\mathrm{a}}\end{array}$ \\
\hline United States & 2.5 & 0.9 & 1.0 & 0.3 & 2.5 & 1.1 & 1.0 & 0.8 \\
\hline Japan & 3.7 & 1.2 & 0.5 & 0.5 & 3.7 & 1.2 & 1.0 & 0.6 \\
\hline Germany & 2.5 & 1.4 & 0.8 & 0.5 & 2.5 & 0.9 & 1.0 & 0.7 \\
\hline France & 3.0 & 1.2 & 0.9 & 0.5 & 3.0 & 1.4 & 1.0 & 0.7 \\
\hline Italy & 2.9 & 0.8 & 0.8 & 0.4 & 2.9 & 0.4 & 1.0 & 0.3 \\
\hline United Kingdom & 4.5 & 1.3 & 1.0 & 0.9 & 4.5 & 1.3 & 1.0 & 1.0 \\
\hline Canada & 2.4 & 1.4 & 0.8 & 0.6 & 2.4 & 1.0 & 1.0 & 0.8 \\
\hline Australia & 2.5 & 1.5 & 0.5 & 0.7 & 2.5 & 0.8 & 1.0 & 0.8 \\
\hline Austria & 2.5 & 1.2 & 1.0 & 0.5 & 2.5 & 1.2 & 1.0 & 0.5 \\
\hline Belgium & 2.5 & 1.2 & 1.0 & 0.5 & 2.5 & 1.2 & 1.0 & 0.8 \\
\hline Denmark & 2.2 & 1.0 & 1.1 & 0.6 & 2.2 & 0.7 & 1.0 & 0.6 \\
\hline Finland & 2.5 & 1.2 & 1.2 & 0.5 & 2.5 & 1.1 & 1.0 & 0.8 \\
\hline Greece & 2.5 & 1.2 & 1.0 & 0.5 & 2.5 & 1.2 & 1.0 & 0.5 \\
\hline Ireland & 2.5 & 1.3 & 1.0 & 0.5 & 2.5 & 1.3 & 1.0 & 0.5 \\
\hline Netherlands & 2.5 & 1.3 & 1.0 & 0.5 & 2.5 & 1.3 & 1.0 & 1.0 \\
\hline Norway & 2.5 & 1.2 & 1.0 & 0.5 & 2.5 & 1.2 & 1.0 & 0.9 \\
\hline Portugal & 2.5 & 1.2 & 1.0 & 0.5 & 2.5 & 1.2 & 1.0 & 0.5 \\
\hline Spain & 2.1 & 1.2 & 1.4 & 0.5 & 2.1 & 1.9 & 1.0 & 1.1 \\
\hline Sweden & 2.4 & 1.3 & 1.6 & 0.5 & 2.4 & 1.4 & 1.0 & 1.2 \\
\hline
\end{tabular}

a) 1991. See Annex for other years. 
Table 5. Cyclical effects on government spending

\begin{tabular}{|c|c|c|c|c|}
\hline & $\begin{array}{c}\text { Elasticity of } \\
\text { unemployment rate } \\
\text { to output }^{\mathrm{a}} \\
\text { A }\end{array}$ & Okun coefficient & $\begin{array}{c}\text { Elasticity of } \\
\text { unemployment-related } \\
\text { expenditure to output } \\
\text { B }\end{array}$ & $\begin{array}{l}\text { Elasticity of current primary } \\
\text { government expenditure to } \\
\text { output }^{\mathrm{b}} \\
\mathrm{C}=\mathrm{A}+\mathrm{B}\end{array}$ \\
\hline United States & 0.5 & 2.0 & -0.2 & -0.1 \\
\hline Japan & 0.1 & 6.7 & -0.4 & -0.1 \\
\hline Germany & 0.3 & 3.3 & -0.6 & -0.2 \\
\hline France & 0.3 & 3.3 & -0.3 & -0.1 \\
\hline Italy & 0.2 & 5.0 & -0.1 & 0.0 \\
\hline United Kingdom & 0.5 & 2.0 & -0.3 & -0.1 \\
\hline Canada & 0.4 & 2.5 & -0.8 & -0.3 \\
\hline Australia & 0.4 & 2.5 & -0.4 & -0.2 \\
\hline Austria & 0.2 & 5.0 & -0.6 & -0.1 \\
\hline Belgium & 0.4 & 2.5 & -0.3 & -0.1 \\
\hline Denmark & 0.4 & 2.5 & -0.6 & -0.2 \\
\hline Finland & 0.3 & 3.3 & -0.4 & -0.1 \\
\hline Ireland & 0.4 & 2.5 & -0.5 & -0.2 \\
\hline Netherlands & 0.5 & 2.0 & -0.5 & -0.2 \\
\hline Norway & 0.2 & 5.0 & -0.4 & -0.1 \\
\hline Spain & 0.6 & 1.7 & -0.4 & -0.3 \\
\hline Sweden & 0.2 & 5.0 & -0.6 & -0.1 \\
\hline Average & 0.35 & 3.34 & -0.44 & -0.14 \\
\hline
\end{tabular}

a) Increase in unemployment rate (in percentage points) following a 1 per cent reduction in GDP against trend.

b) Expressed as a percent of government expenditure. 
Table 6. Unemployment expenditure and total general government expenditure Per cent of GDP, 1993

\begin{tabular}{|c|c|c|c|}
\hline Country & $\begin{array}{c}\text { Unemployment } \\
\text { expenditure/GDP }\end{array}$ & $\begin{array}{l}\text { General government } \\
\text { expenditure/GDP }\end{array}$ & $\begin{array}{c}\text { Unemployment } \\
\text { expenditure/government } \\
\text { expenditure }\end{array}$ \\
\hline United States & $0.7^{\mathrm{b}}$ & 34.5 & 2.0 \\
\hline Japan & $0.4^{\mathrm{c}}$ & 34.0 & 1.0 \\
\hline Germany & 4.2 & 49.4 & 8.5 \\
\hline France & $3.0^{\mathrm{d}}$ & 54.9 & 5.5 \\
\hline Italy & $1.8^{\mathrm{d}}$ & 56.2 & 3.3 \\
\hline United Kingdom & $1.8^{\mathrm{b}}$ & 43.6 & 4.0 \\
\hline Canada & $2.7^{\mathrm{b}}$ & 49.7 & 5.3 \\
\hline Australia & $2.7^{\mathrm{c}}$ & 37.7 & 7.1 \\
\hline Austria & 1.8 & 52.9 & 3.3 \\
\hline Belgium & $4.0^{\mathrm{d}}$ & 58.2 & 6.9 \\
\hline Denmark & 6.8 & 63.1 & 10.7 \\
\hline Finland & 6.9 & 61.0 & 11.3 \\
\hline Greece & $1.2^{\mathrm{d}}$ & 52.4 & 2.3 \\
\hline Ireland & $4.3^{\mathrm{e}}$ & 43.6 & 9.8 \\
\hline Netherlands & $3.4^{\mathrm{d}}$ & 55.9 & 6.0 \\
\hline Norway & 2.9 & 57.1 & 5.1 \\
\hline Portugal & 1.9 & 52.9 & 3.6 \\
\hline Spain & 4.0 & 47.1 & 8.4 \\
\hline Sweden & $5.7^{\mathrm{b}}$ & 71.6 & 7.9 \\
\hline
\end{tabular}
a) Employment Outlook 1994. Table 1.8.2 (Active and passive measures).
b) 1993-1994 fiscal year.
c) 1992-1993 fiscal year.
d) 1992 .
e) 1991 . 
Table 7. Comparison of actual and structural budget balances Surplus (+) or deficit (-) as a per cent of GDP

\begin{tabular}{|c|c|c|c|c|c|c|c|c|c|}
\hline & Actual & $\begin{array}{l}\text { Previous } \\
\text { method }^{\mathrm{b}}\end{array}$ & Potential $^{\mathrm{b}}$ & Potential $^{\mathrm{c}}$ & & Actual & $\begin{array}{l}\text { Previous } \\
\text { method }^{\mathrm{b}}\end{array}$ & Potential $^{\mathrm{b}}$ & Potential $^{c}$ \\
\hline United States & & & & & Italy & & & & \\
\hline 1987 & -2.5 & -2.8 & -2.5 & -2.5 & 1987 & -11.0 & -10.5 & -11.7 & -11.5 \\
\hline 1988 & -2.0 & -2.8 & -2.5 & -2.6 & 1988 & -10.7 & -11.0 & -12.1 & -11.8 \\
\hline 1989 & -1.5 & -2.3 & -2.2 & -2.3 & 1989 & -9.9 & -10.5 & -12.0 & -11.5 \\
\hline 1990 & -2.5 & -3.1 & -3.1 & -3.1 & 1990 & -10.9 & -11.4 & -12.9 & -12.4 \\
\hline 1991 & -3.2 & -3.4 & -3.4 & -3.4 & 1991 & -10.2 & -10.1 & -11.6 & -11.2 \\
\hline 1992 & -4.3 & -3.8 & -3.8 & -3.8 & 1992 & -9.5 & -8.5 & -10.0 & -9.8 \\
\hline 1993 & -3.4 & -3.2 & -3.2 & -3.2 & 1993 & -9.6 & -6.9 & -8.4 & -8.7 \\
\hline 1994 & -2.0 & -2.3 & -2.3 & -2.3 & 1994 & -9.7 & -6.9 & -8.6 & -8.9 \\
\hline 1995 & -1.8 & -2.3 & -2.3 & -2.3 & 1995 & -9.1 & -6.5 & -8.3 & -8.5 \\
\hline 1996 & -1.8 & -2.3 & -2.2 & -2.3 & 1996 & -7.8 & -5.5 & -7.4 & -7.5 \\
\hline Average 87-96 & -2.5 & -2.8 & -2.8 & -2.8 & Average 87-96 & -9.8 & -8.8 & -10.3 & -10.2 \\
\hline Japan & & & & & United Kingdom & & & & \\
\hline 1987 & 0.5 & 1.3 & 2.1 & 2.2 & 1987 & -1.4 & -2.9 & -2.8 & -2.7 \\
\hline 1988 & 1.5 & 1.5 & 2.0 & 2.0 & 1988 & 1.0 & -1.8 & -1.6 & -1.4 \\
\hline 1989 & 2.5 & 2.2 & 2.5 & 2.4 & 1989 & 0.9 & -1.9 & -1.6 & -1.5 \\
\hline 1990 & 2.9 & 2.3 & 2.2 & 2.1 & 1990 & -1.2 & -3.0 & -2.6 & -2.5 \\
\hline 1991 & 3.0 & 2.4 & 1.9 & 1.9 & 1991 & -2.7 & -2.2 & -1.7 & -1.7 \\
\hline 1992 & 1.8 & 2.0 & 1.1 & 1.0 & 1992 & -6.2 & -4.2 & -3.5 & -3.7 \\
\hline 1993 & -0.2 & 1.4 & -0.1 & -0.1 & 1993 & -7.7 & -5.4 & -4.8 & -5.0 \\
\hline 1994 & -2.0 & 0.6 & -1.0 & -1.0 & 1994 & -6.8 & -5.1 & -4.5 & -4.7 \\
\hline 1995 & -1.8 & 1.1 & -0.6 & -0.6 & 1995 & -4.7 & -3.6 & -3.0 & -3.1 \\
\hline 1996 & -1.8 & 1.2 & -0.8 & -0.7 & 1996 & -3.2 & -2.5 & -1.9 & -2.0 \\
\hline Average $87-96$ & 0.6 & 1.6 & 0.9 & 0.9 & Average 87-96 & -3.2 & -3.3 & -2.8 & -2.8 \\
\hline Germany & & & & & Canada & & & & \\
\hline 1987 & -1.9 & -0.5 & -1.0 & -0.9 & 1987 & -3.8 & -4.4 & -5.1 & -5.1 \\
\hline 1988 & -2.2 & -1.5 & -1.9 & -1.9 & 1988 & -2.5 & -4.1 & -4.7 & -4.8 \\
\hline 1989 & 0.1 & 0.1 & 0.0 & 0.0 & 1989 & -2.9 & -4.3 & -4.9 & -5.0 \\
\hline 1990 & -2.0 & -3.6 & -3.2 & -3.2 & 1990 & -4.1 & -4.0 & -4.6 & -4.6 \\
\hline 1991 & -3.3 & -5.5 & -4.8 & -4.9 & 1991 & -6.6 & -4.2 & -4.7 & -4.6 \\
\hline 1992 & -2.9 & -5.2 & -4.2 & -4.3 & 1992 & -7.1 & -3.6 & -4.4 & -4.2 \\
\hline 1993 & -3.3 & -3.5 & -2.7 & -2.7 & 1993 & -7.1 & -3.5 & -4.6 & -4.5 \\
\hline 1994 & -2.7 & -2.9 & -2.1 & -2.1 & 1994 & -6.2 & -3.3 & -4.6 & -4.5 \\
\hline 1995 & -2.4 & -2.7 & -1.8 & -1.8 & 1995 & -4.7 & -2.4 & -3.7 & -3.7 \\
\hline 1996 & -1.8 & -2.5 & -1.5 & -1.5 & 1996 & -3.5 & -1.8 & -3.1 & -3.0 \\
\hline Average 87-96 & -2.2 & -2.8 & -2.3 & -2.3 & Average 87-96 & -4.8 & -3.6 & -4.4 & -4.4 \\
\hline France & & & & & Australia & & & & \\
\hline 1987 & -1.9 & -0.3 & -0.7 & -0.7 & 1987 & -0.1 & -0.3 & -0.3 & -0.3 \\
\hline 1988 & -1.7 & -1.0 & -1.4 & -1.4 & 1988 & 1.2 & 0.9 & 0.7 & 0.8 \\
\hline 1989 & -1.2 & -1.4 & -1.7 & -1.8 & 1989 & 1.2 & 0.8 & 0.4 & 0.4 \\
\hline 1990 & -1.6 & -1.8 & -2.2 & -2.2 & 1990 & 0.5 & 0.5 & 0.2 & 0.2 \\
\hline 1991 & -2.2 & -1.6 & -2.1 & -2.1 & 1991 & -2.8 & -1.2 & -1.5 & -1.6 \\
\hline 1992 & -3.9 & -2.7 & -3.4 & -3.4 & 1992 & -3.9 & -1.7 & -2.1 & -2.2 \\
\hline 1993 & -5.8 & -2.8 & -3.9 & -3.8 & 1993 & -3.7 & -1.8 & -2.2 & -2.3 \\
\hline 1994 & -5.7 & -2.5 & -3.8 & -3.7 & 1994 & -4.0 & -2.7 & -3.2 & -3.2 \\
\hline 1995 & -5.0 & -2.1 & -3.6 & -3.5 & 1995 & -2.9 & -2.3 & -2.7 & -2.7 \\
\hline 1996 & -4.0 & -1.4 & -3.1 & -3.1 & 1996 & -1.8 & -1.8 & -2.0 & -2.0 \\
\hline Average $87-96$ & -3.3 & -1.8 & -2.6 & -2.6 & Average $87-96$ & -1.6 & -1.0 & -1.3 & -1.3 \\
\hline
\end{tabular}


Table 7 (continued)

\begin{tabular}{|c|c|c|c|c|c|c|c|c|c|}
\hline & Actual & $\begin{array}{l}\text { Previous } \\
\text { method }^{\text {b }}\end{array}$ & Potential $^{\mathrm{b}}$ & Potential $^{\mathrm{c}}$ & & Actual & $\begin{array}{l}\text { Previous } \\
\text { method }^{\mathrm{b}}\end{array}$ & Potential $^{\mathrm{b}}$ & Potential $^{c}$ \\
\hline Austria & & & & & Greece & & & & \\
\hline 1987 & -4.3 & -3.0 & -1.8 & -2.0 & 1987 & -10.9 & -9.9 & -9.0 & -9.0 \\
\hline 1988 & -3.0 & -2.7 & -1.8 & -1.9 & 1988 & -12.4 & -12.7 & -11.9 & -11.9 \\
\hline 1989 & -2.8 & -2.9 & -2.5 & -2.5 & 1989 & -14.5 & -15.8 & -15.0 & -15.0 \\
\hline 1990 & -2.1 & -2.9 & -2.6 & -2.5 & 1990 & -13.9 & -14.0 & -13.2 & -13.2 \\
\hline 1991 & -2.5 & -3.1 & -2.8 & -2.8 & 1991 & -13.0 & -13.7 & -13.1 & -13.1 \\
\hline 1992 & -2.0 & -1.9 & -2.1 & -2.1 & 1992 & -11.8 & -12.1 & -11.7 & -11.7 \\
\hline 1993 & -4.2 & -2.7 & -2.9 & -3.0 & 1993 & -13.5 & -12.7 & -12.5 & -12.5 \\
\hline 1994 & -4.2 & -2.9 & -3.2 & -3.5 & 1994 & -13.1 & -11.8 & -11.8 & -11.8 \\
\hline 1995 & -5.0 & -4.2 & -4.4 & -4.7 & 1995 & -11.6 & -10.3 & -10.4 & -10.4 \\
\hline 1996 & -4.5 & -4.1 & -4.3 & -4.7 & 1996 & -10.1 & -9.0 & -9.3 & -9.3 \\
\hline Average 87-96 & -3.5 & -3.0 & -2.8 & -3.0 & Average 87-96 & -12.5 & -12.2 & -11.8 & -11.8 \\
\hline Belgium & & & & & Ireland & & & & \\
\hline 1987 & -7.4 & -5.7 & -5.8 & -5.8 & 1987 & -8.5 & -7.2 & -6.3 & -6.3 \\
\hline 1988 & -6.6 & -6.7 & -6.4 & -6.4 & 1988 & -4.5 & -3.0 & -2.5 & -2.5 \\
\hline 1989 & -6.3 & -7.2 & -6.7 & -6.7 & 1989 & -1.7 & -1.6 & -0.9 & -0.9 \\
\hline 1990 & -5.4 & -7.1 & -6.4 & -6.4 & 1990 & -2.2 & -3.9 & -2.9 & -2.9 \\
\hline 1991 & -6.5 & -8.4 & -7.5 & -7.5 & 1991 & -2.1 & -3.0 & -2.0 & -2.0 \\
\hline 1992 & -6.7 & -8.5 & -7.5 & -7.5 & 1992 & -2.2 & -3.3 & -2.3 & -2.3 \\
\hline 1993 & -6.6 & -6.2 & -5.2 & -5.2 & 1993 & -2.4 & -3.2 & -2.3 & -2.3 \\
\hline 1994 & -5.3 & -5.0 & -4.0 & -4.0 & 1994 & -2.3 & -3.2 & -2.2 & -2.2 \\
\hline 1995 & -4.6 & -5.0 & -3.8 & -3.8 & 1995 & -2.0 & -3.0 & -2.3 & -2.3 \\
\hline 1996 & -4.1 & -5.1 & -3.7 & -3.7 & 1996 & -2.0 & -3.0 & -2.5 & -2.5 \\
\hline Average 87-96 & -5.9 & -6.5 & -5.7 & -5.7 & Average 87-96 & -3.0 & -3.4 & -2.6 & -2.6 \\
\hline Denmark & & & & & Netherlands & & & & \\
\hline 1987 & 2.4 & 1.8 & 1.9 & 1.9 & 1987 & -5.1 & -3.8 & -3.0 & -2.6 \\
\hline 1988 & 0.6 & 0.5 & 0.9 & 0.9 & 1988 & -4.2 & -3.1 & -2.2 & -1.8 \\
\hline 1989 & -0.5 & 0.3 & 0.6 & 0.4 & 1989 & -4.7 & -5.0 & -4.0 & -3.9 \\
\hline 1990 & -1.5 & -0.3 & 0.1 & -0.2 & 1990 & -5.1 & -6.6 & -5.4 & -5.5 \\
\hline 1991 & -2.1 & -0.2 & 0.3 & -0.1 & 1991 & -2.8 & -4.3 & -3.0 & -3.0 \\
\hline 1992 & -2.6 & -0.2 & 0.2 & -0.3 & 1992 & -3.8 & -4.9 & -3.5 & -3.4 \\
\hline 1993 & -4.4 & -1.5 & -1.4 & -1.9 & 1993 & -3.3 & -3.3 & -1.9 & -1.6 \\
\hline 1994 & -4.2 & -3.0 & -2.8 & -3.0 & 1994 & -3.8 & -3.9 & -2.6 & -2.3 \\
\hline 1995 & -3.0 & -2.7 & -2.4 & -2.5 & 1995 & -3.6 & -4.1 & -2.8 & -2.6 \\
\hline 1996 & -2.2 & -2.5 & -2.1 & -2.1 & 1996 & -2.9 & -4.0 & -2.5 & -2.4 \\
\hline Average 87-96 & -1.7 & -0.8 & -0.5 & -0.7 & Average 87-96 & -3.9 & -4.3 & -3.1 & -2.9 \\
\hline Finland & & & & & Norway (mainland) & & & & \\
\hline 1987 & 1.1 & -0.7 & -1.0 & -0.8 & 1987 & 2.2 & -1.1 & -0.8 & -0.9 \\
\hline 1988 & 4.1 & 1.1 & 0.3 & 0.7 & 1988 & 1.0 & -0.7 & 0.0 & 0.0 \\
\hline 1989 & 6.3 & 1.5 & 0.5 & 1.2 & 1989 & -3.0 & -2.2 & -1.8 & -1.8 \\
\hline 1990 & 5.4 & 0.7 & 0.1 & 0.7 & 1990 & -4.4 & -3.0 & -3.2 & -3.2 \\
\hline 1991 & -1.5 & -1.6 & -2.0 & -2.0 & 1991 & -7.7 & -4.7 & -5.2 & -5.2 \\
\hline 1992 & -5.8 & -3.1 & -3.5 & -3.7 & 1992 & -9.7 & -6.6 & -7.2 & -7.3 \\
\hline 1993 & -7.1 & -2.6 & -3.1 & -3.4 & 1993 & -10.4 & -7.3 & -8.2 & -8.3 \\
\hline 1994 & -4.6 & -1.7 & -1.5 & -1.7 & 1994 & -8.4 & -6.2 & -6.9 & -6.9 \\
\hline 1995 & -5.1 & -4.6 & -3.6 & -3.7 & 1995 & -7.2 & -5.7 & -6.3 & -6.3 \\
\hline 1996 & -3.3 & -4.5 & -2.5 & -2.6 & 1996 & -6.7 & -5.7 & -6.1 & -6.1 \\
\hline Average 87-96 & -1.0 & -1.6 & -1.6 & -1.5 & Average 87-96 & -5.4 & -4.3 & -4.6 & -4.6 \\
\hline
\end{tabular}


Table 7 (continued)

\begin{tabular}{|c|c|c|c|c|c|c|c|c|c|}
\hline & Actual & $\begin{array}{l}\text { Previous } \\
\text { method }^{\text {b }}\end{array}$ & Potential $^{\mathrm{b}}$ & Potential $^{c}$ & & Actual & $\begin{array}{l}\text { Previous } \\
\text { method }^{\text {b }}\end{array}$ & Potential $^{\mathrm{b}}$ & Potential $^{\mathrm{c}}$ \\
\hline Portugal & & & & & Sweden & & & & \\
\hline 1987 & -7.3 & -6.3 & -6.3 & -6.3 & 1987 & 4.2 & 0.8 & 1.9 & 2.0 \\
\hline 1988 & -5.4 & -4.9 & -4.9 & -4.9 & 1988 & 3.5 & -0.4 & 0.8 & 0.9 \\
\hline 1989 & -3.1 & -3.4 & -3.4 & -3.4 & 1989 & 5.4 & 0.8 & 2.5 & 2.6 \\
\hline 1990 & -5.4 & -6.7 & -6.7 & -6.7 & 1990 & 4.2 & -0.3 & 0.6 & 0.8 \\
\hline 1991 & -6.1 & -7.4 & -7.4 & -7.4 & 1991 & -1.1 & -3.7 & -2.6 & -2.6 \\
\hline 1992 & -3.8 & -4.5 & -4.5 & -4.5 & 1992 & -7.4 & -7.5 & -6.3 & -6.4 \\
\hline 1993 & -8.0 & -6.9 & -6.9 & -6.9 & 1993 & -13.5 & -10.7 & -9.7 & -9.9 \\
\hline 1994 & -7.1 & -5.2 & -5.2 & -5.2 & 1994 & -11.2 & -9.3 & -8.4 & -8.5 \\
\hline 1995 & -6.6 & -4.6 & -4.6 & -4.6 & 1995 & -10.2 & -9.2 & -8.2 & -8.2 \\
\hline 1996 & -5.5 & -3.7 & -3.7 & -3.7 & 1996 & -9.7 & -9.6 & -8.3 & -8.4 \\
\hline Average $87-96$ & -5.8 & -5.3 & -5.3 & -5.3 & Average $87-96$ & -3.6 & -4.9 & -3.8 & -3.8 \\
\hline \multicolumn{10}{|l|}{ Spain } \\
\hline 1987 & -3.1 & -3.2 & -2.7 & -2.6 & & & & & \\
\hline 1988 & -3.3 & -4.3 & -3.8 & -3.9 & & & & & \\
\hline 1989 & -2.8 & -4.7 & -4.0 & -4.3 & & & & & \\
\hline 1990 & -4.1 & -6.4 & -5.5 & -5.9 & & & & & \\
\hline 1991 & -4.9 & -6.8 & -5.9 & -6.2 & & & & & \\
\hline 1992 & -4.2 & -5.0 & -4.2 & -4.2 & & & & & \\
\hline 1993 & -7.5 & -6.2 & -6.0 & -5.5 & & & & & \\
\hline 1994 & -6.8 & -4.9 & -5.2 & -4.7 & & & & & \\
\hline 1995 & -6.1 & -4.1 & -4.5 & -4.0 & & & & & \\
\hline 1996 & -5.2 & -3.5 & -3.9 & -3.5 & & & & & \\
\hline Average $87-96$ & -4.8 & -4.9 & -4.6 & -4.5 & & & & & \\
\hline
\end{tabular}

a) Structural balances calculated using the previous method are expressed as a per cent of trend GDP derived using the previous method. Structural balances calculated using the potential GDP are expressed as a per cent of potential GDP.

b) Using old elasticities.

c) Using new elasticities. 
Table 8. Changes in fiscal balances ${ }^{\mathrm{a}}$

\begin{tabular}{|c|c|c|c|c|c|c|c|}
\hline & \multirow{2}{*}{$\begin{array}{l}\text { Actual } \\
\text { balance }\end{array}$} & \multicolumn{2}{|c|}{ Structural balances } & & \multirow{2}{*}{$\begin{array}{l}\text { Actual } \\
\text { balance }\end{array}$} & \multicolumn{2}{|c|}{ Structural balances } \\
\hline & & $\begin{array}{l}\text { Previous } \\
\text { method }^{\text {b }}\end{array}$ & Potential $^{c}$ & & & $\begin{array}{l}\text { Previous } \\
\text { method }^{\mathrm{b}}\end{array}$ & Potential $^{\mathrm{c}}$ \\
\hline United States & & & & Canada & & & \\
\hline 1993 & 0.9 & 0.6 & 0.6 & 1993 & 0.0 & 0.1 & -0.3 \\
\hline 1994 & 1.4 & 0.9 & 0.8 & 1994 & 0.9 & 0.1 & 0.0 \\
\hline 1995 & 0.2 & 0.0 & 0.0 & 1995 & 1.6 & 0.9 & 0.8 \\
\hline 1996 & -0.1 & 0.0 & 0.1 & 1996 & 1.1 & 0.7 & 0.6 \\
\hline 1993-1996 & 2.4 & 1.5 & 1.5 & 1993-1996 & 3.6 & 1.8 & 1.2 \\
\hline Japan & & & & Australia & & & \\
\hline 1993 & -2.0 & -0.6 & -1.1 & 1993 & 0.2 & -0.1 & -0.1 \\
\hline 1994 & -1.8 & -0.9 & -0.9 & 1994 & -0.3 & -0.9 & -0.9 \\
\hline 1995 & 0.2 & 0.6 & 0.4 & 1995 & 1.1 & 0.4 & 0.5 \\
\hline 1996 & 0.0 & 0.1 & 0.2 & 1996 & 1.1 & 0.5 & 0.7 \\
\hline 1993-1996 & -3.7 & -0.8 & -1.7 & 1993-1996 & 2.1 & -0.1 & 0.2 \\
\hline Germany & & & & Austria & & & \\
\hline 1993 & -0.4 & 1.7 & 1.6 & 1993 & -2.2 & -0.8 & -0.9 \\
\hline 1994 & 0.6 & 0.6 & 0.6 & 1994 & 0.0 & -0.3 & -0.3 \\
\hline 1995 & 0.4 & 0.3 & 0.3 & 1995 & -0.8 & -1.2 & -1.2 \\
\hline 1996 & 0.6 & 0.2 & 0.3 & 1996 & 0.5 & 0.0 & 0.2 \\
\hline 1993-1996 & 1.2 & 2.7 & 2.8 & 1993-1996 & -2.5 & -2.2 & -2.3 \\
\hline France & & & & Belgium & & & \\
\hline 1993 & -1.9 & -0.1 & -0.4 & 1993 & 0.1 & 2.3 & 2.3 \\
\hline 1994 & 0.1 & 0.4 & -0.1 & 1994 & 1.3 & 1.1 & 1.2 \\
\hline 1995 & 0.7 & 0.4 & 0.2 & 1995 & 0.6 & 0.0 & 0.2 \\
\hline 1996 & 1.0 & 0.7 & 0.5 & 1996 & 0.5 & -0.1 & 0.1 \\
\hline 1993-1996 & -0.1 & 1.3 & 0.3 & 1993-1996 & 2.6 & 3.4 & 3.8 \\
\hline Italy & & & & Denmark & & & \\
\hline 1993 & 0.0 & 1.6 & 1.1 & 1993 & -1.8 & -1.3 & -1.6 \\
\hline 1994 & -0.1 & 0.0 & -0.2 & 1994 & 0.2 & -1.5 & -1.1 \\
\hline 1995 & 0.6 & 0.4 & 0.4 & 1995 & 1.2 & 0.3 & 0.5 \\
\hline 1996 & 1.3 & 1.0 & 1.0 & 1996 & 0.8 & 0.2 & 0.3 \\
\hline 1993-1996 & 1.7 & 3.0 & 2.3 & 1993-1996 & 0.4 & -2.4 & -1.9 \\
\hline United Kingdom & & & & Finland & & & \\
\hline 1993 & -1.5 & -1.3 & -1.3 & 1993 & -1.3 & 0.4 & 0.3 \\
\hline 1994 & 0.9 & 0.3 & 0.3 & 1994 & 2.5 & 0.9 & 1.7 \\
\hline 1995 & 2.1 & 1.5 & 1.5 & 1995 & -0.5 & -2.9 & -2.0 \\
\hline 1996 & 1.5 & 1.1 & 1.2 & 1996 & 1.8 & 0.1 & 1.1 \\
\hline 1993-1996 & 3.0 & 1.7 & 1.7 & 1993-1996 & 2.6 & -1.4 & 1.2 \\
\hline
\end{tabular}


Table 8. Continued

\begin{tabular}{|c|c|c|c|c|c|c|c|}
\hline & \multirow{2}{*}{$\begin{array}{l}\text { Actual } \\
\text { balance }\end{array}$} & \multicolumn{2}{|c|}{ Structural balances } & & \multirow{2}{*}{$\begin{array}{c}\text { Actual } \\
\text { balance }\end{array}$} & \multicolumn{2}{|c|}{ Structural balances } \\
\hline & & $\begin{array}{l}\text { Previous } \\
\text { method }^{\mathrm{b}}\end{array}$ & Potential $^{\mathrm{c}}$ & & & $\begin{array}{l}\text { Previous } \\
\text { method }^{\mathrm{b}}\end{array}$ & Potential $^{\mathrm{c}}$ \\
\hline Greece & & & & Portugal & & & \\
\hline 1993 & -1.7 & -0.5 & -0.8 & 1993 & -4.2 & -2.5 & -2.5 \\
\hline 1994 & -0.4 & 0.8 & 0.7 & 1994 & 0.9 & 1.8 & 1.8 \\
\hline 1995 & 1.4 & 1.5 & 1.4 & 1995 & 0.5 & 0.6 & 0.6 \\
\hline 1996 & 1.5 & 1.3 & 1.1 & 1996 & 1.1 & 0.9 & 0.9 \\
\hline 1993-1996 & 1.7 & 3.1 & 2.4 & 1993-1996 & -1.6 & 0.8 & 0.8 \\
\hline Ireland & & & & Spain & & & \\
\hline 1993 & -0.2 & 0.1 & 0.0 & 1993 & -3.3 & -1.2 & -1.3 \\
\hline 1994 & 0.2 & 0.0 & 0.1 & 1994 & 0.7 & 1.3 & 0.8 \\
\hline 1995 & 0.3 & 0.2 & 0.0 & 1995 & 0.8 & 0.8 & 0.6 \\
\hline 1996 & 0.0 & 0.0 & -0.2 & 1996 & 0.9 & 0.7 & 0.5 \\
\hline 1993-1996 & 0.2 & 0.3 & -0.2 & 1993-1996 & -1.0 & 1.6 & 0.7 \\
\hline Netherlands & & & & Sweden & & & \\
\hline 1993 & 0.6 & 1.7 & 1.8 & 1993 & -6.1 & -3.1 & -3.5 \\
\hline 1994 & -0.5 & -0.6 & -0.7 & 1994 & 2.3 & 1.4 & 1.4 \\
\hline 1995 & 0.2 & -0.2 & -0.3 & 1995 & 0.9 & 0.1 & 0.3 \\
\hline 1996 & 0.7 & 0.2 & 0.2 & 1996 & 0.6 & 0.4 & 0.2 \\
\hline 1993-1996 & 0.9 & 1.0 & 1.0 & 1993-1996 & -2.3 & -1.0 & -2.0 \\
\hline \multicolumn{8}{|c|}{ Norway (mainland) } \\
\hline 1993 & -0.7 & -0.8 & -1.0 & & & & \\
\hline 1994 & 2.0 & 1.1 & 1.4 & & & & \\
\hline 1995 & 1.2 & 0.5 & 0.6 & & & & \\
\hline 1996 & 0.5 & 0.0 & 0.2 & & & & \\
\hline 1993-1996 & 3.0 & 0.9 & 1.2 & & & & \\
\hline
\end{tabular}

a) Structural balances calculated using the previous method are expressed as a per cent of trend GDP derived using the previous method. Structural balances calculated using the potential GDP are expressed as a per cent of potential GDP.

b) Using old elasticities.

c) Using new elasticities. 


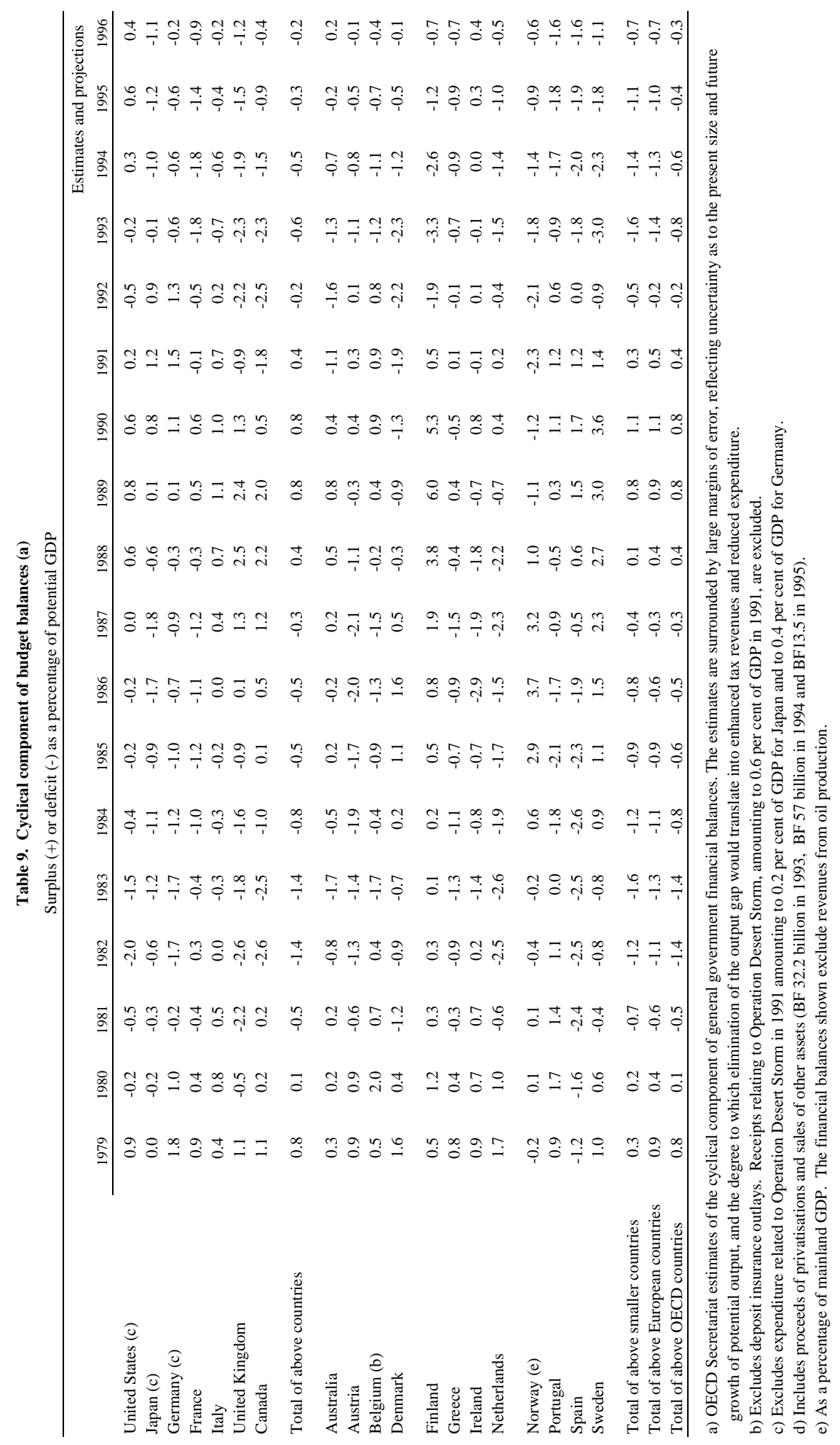


Figure 1. Output growth and output gaps

__ Trend GDP: previous method _..._. Trend GDP: HP filter(a)

Potential output

Actual GDP

Output growth

\section{Output gap}

\section{United States}
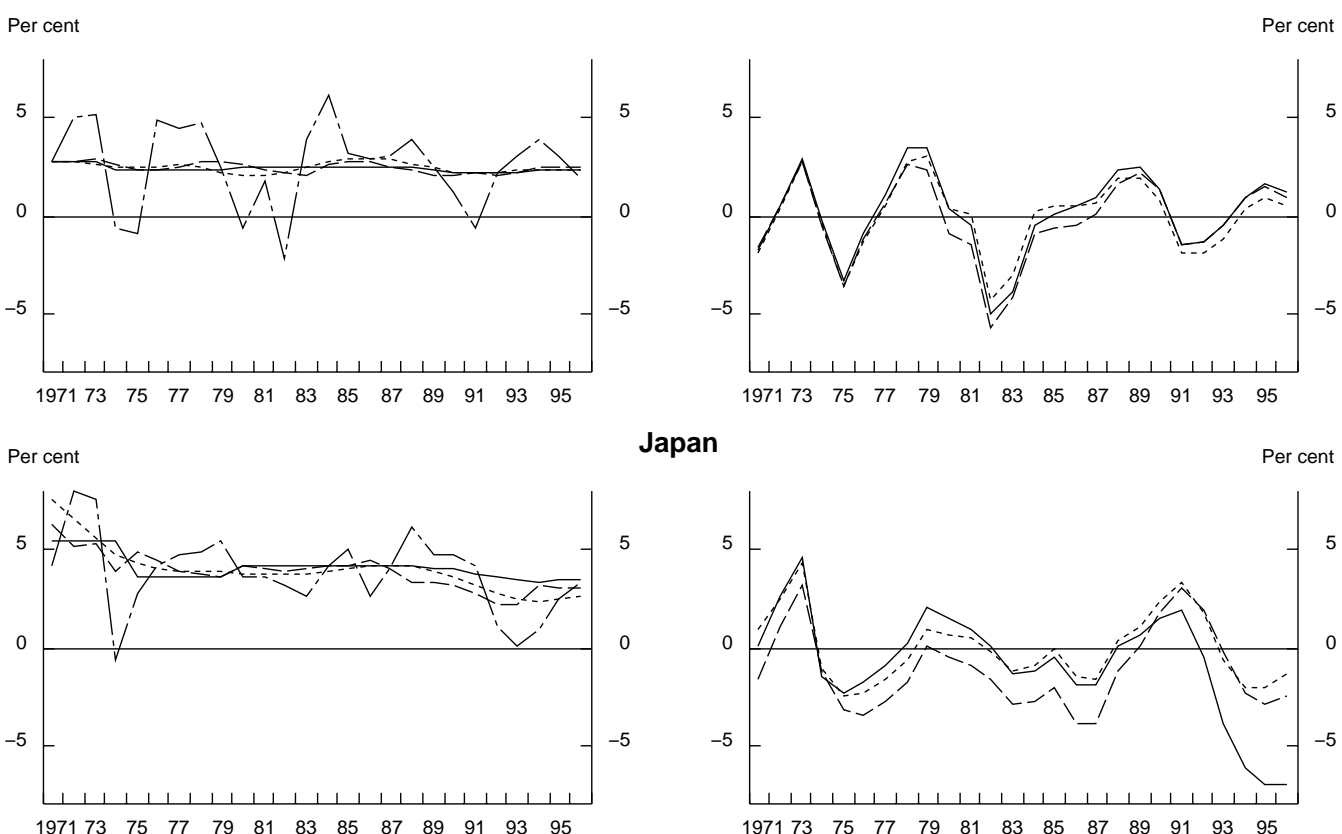

Japan
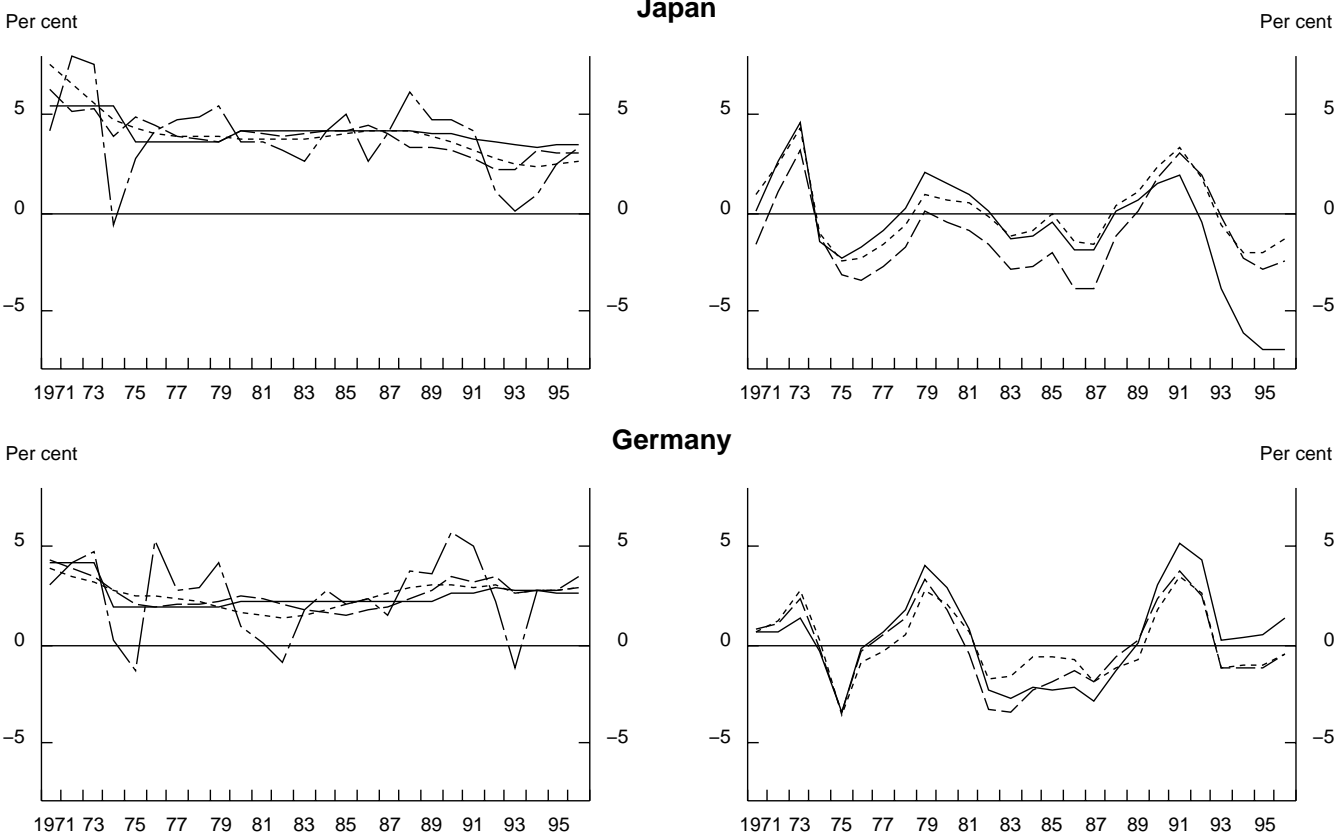

Germany
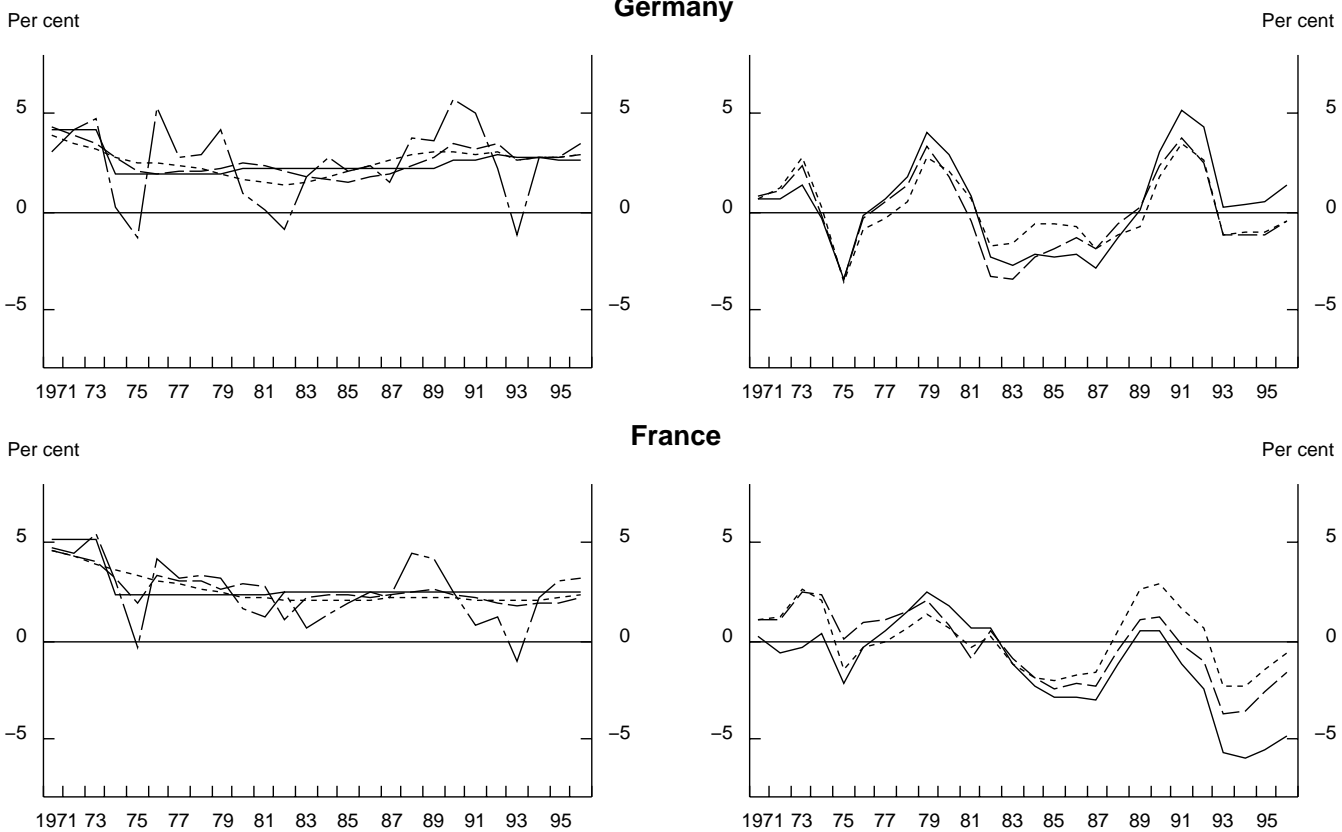

France

Per cent

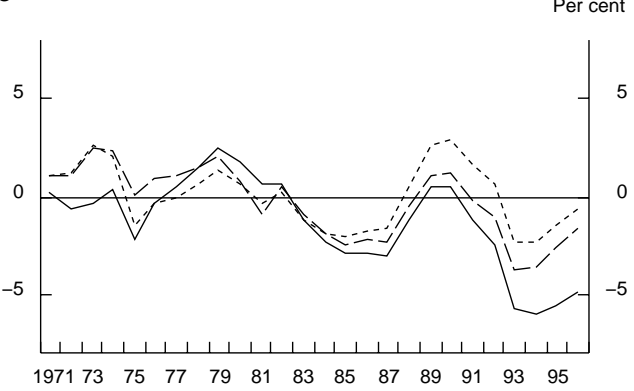

a. Using lambda=25, except for France and United Kingdom (100) and Canada (200). 
Figure 1(cont.). Output growth and output gaps

\section{Output growth}

Per cent

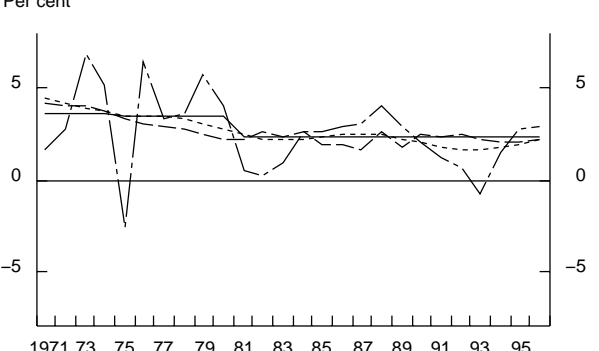

Italy

Output gap

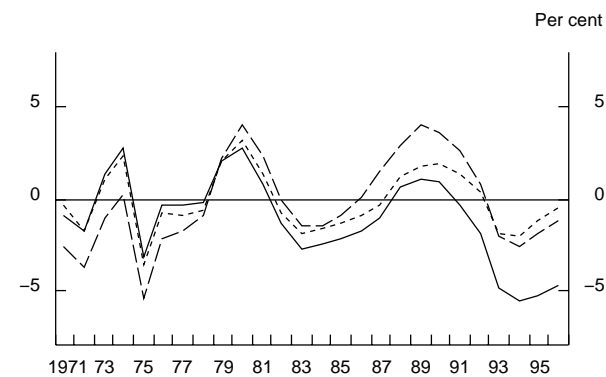

Per cent

United Kingdom

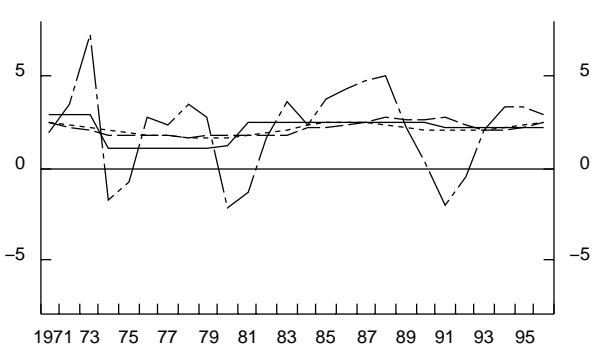

Per cent

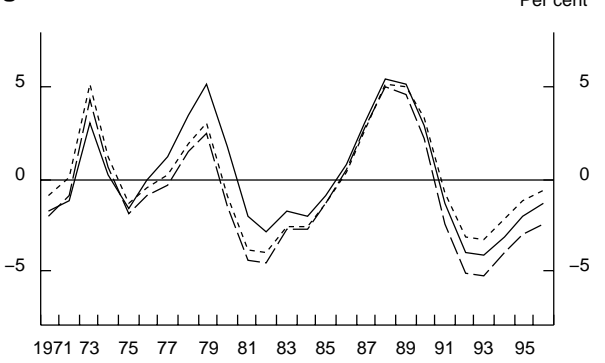

Canada
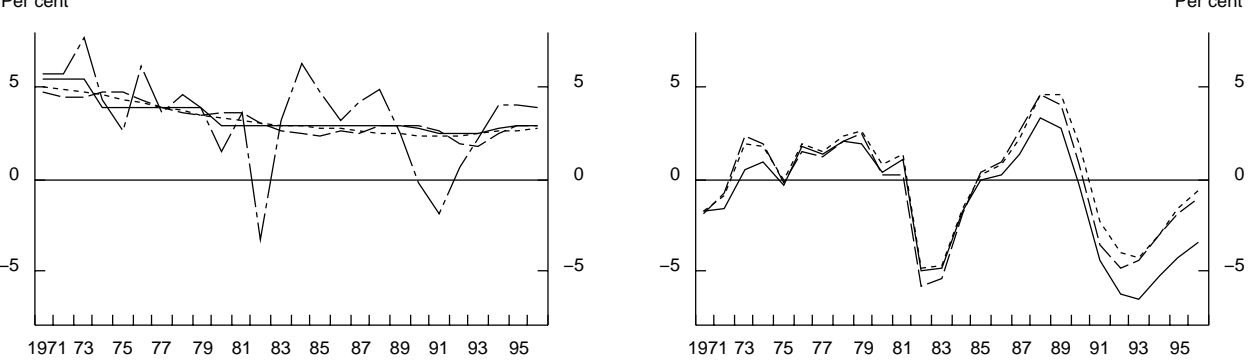

Australia
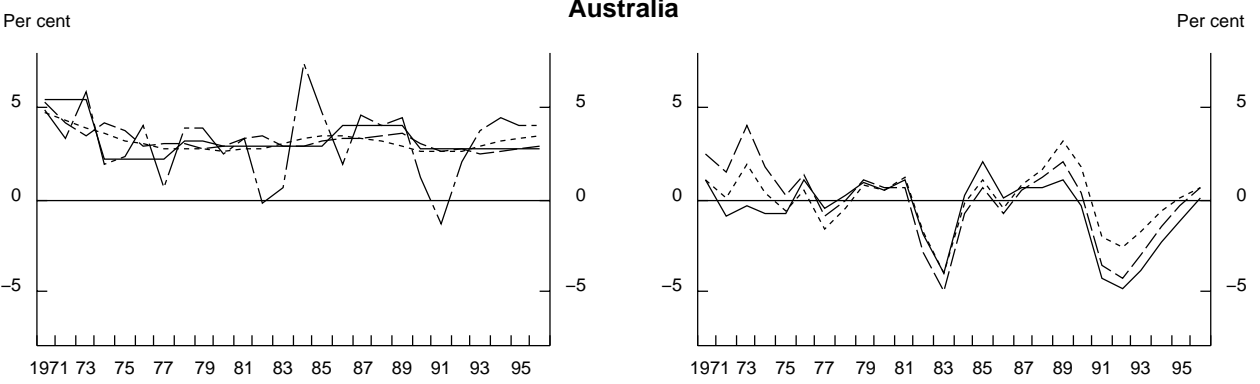
Figure 1(cont.). Output growth and output gaps

_ Trend GDP: previous method

Trend GDP: HP filter(a)

Potential output

Actual GDP

Output growth

Austria

Output gap

Per cent

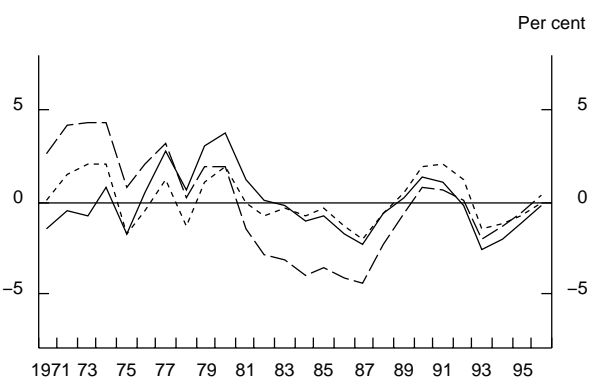

$\begin{array}{llllllllllllll}1971 & 73 & 75 & 77 & 79 & 81 & 83 & 85 & 87 & 89 & 91 & 93 & 95\end{array}$

$\begin{array}{lllllllllllll}1971 & 73 & 75 & 77 & 79 & 81 & 83 & 85 & 87 & 89 & 91 & 93 & 95\end{array}$

Per cent

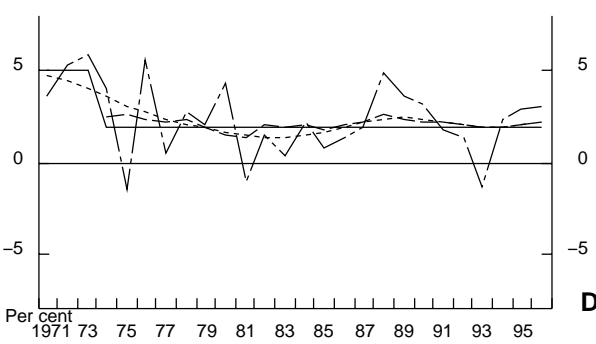

Belgium

Denmark
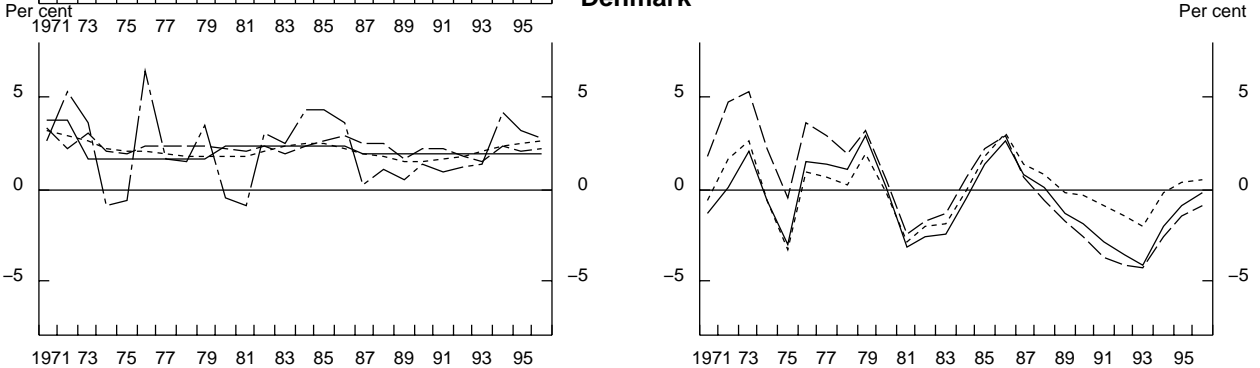

Per cent

Finland (b)
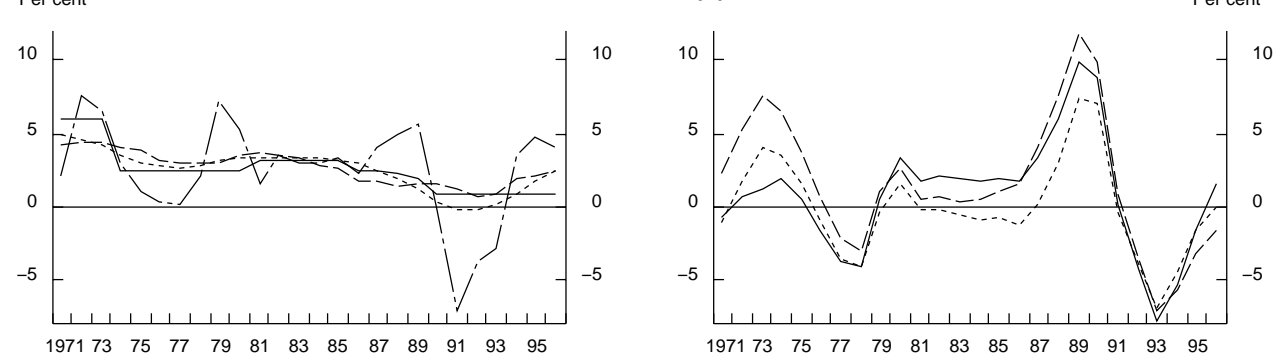

a. Using lambda $=25$.

b. Different scale. 
Figure 1(cont.). Output growth and output gaps

_ Trend GDP: previous method

Trend GDP: HP filter(a)

Potential output

Actual GDP

Output growth

Per cent

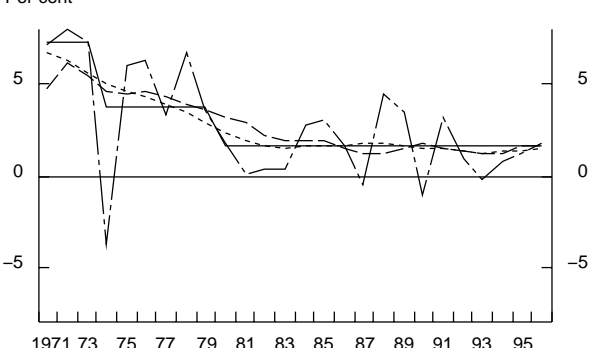

Greece (b)

Output gap

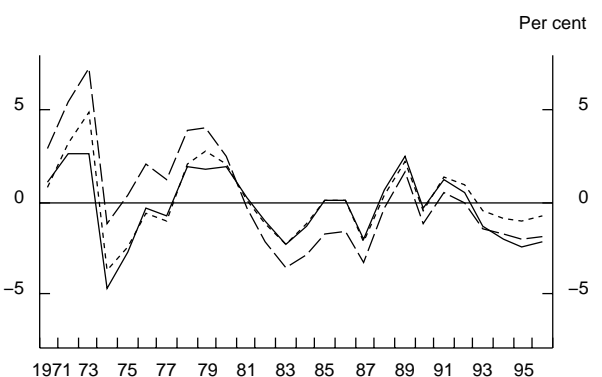

Ireland

Per cent

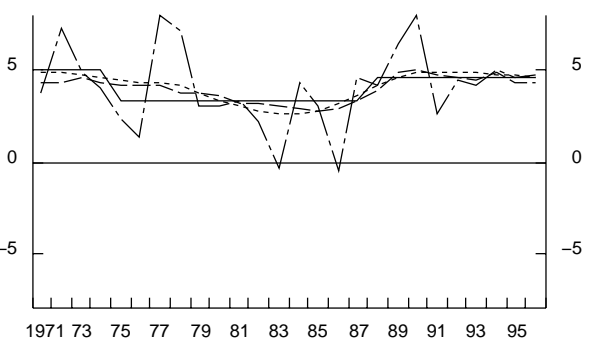

Per cent

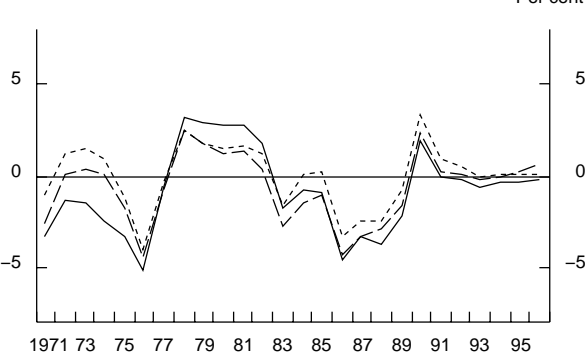

Netherlands
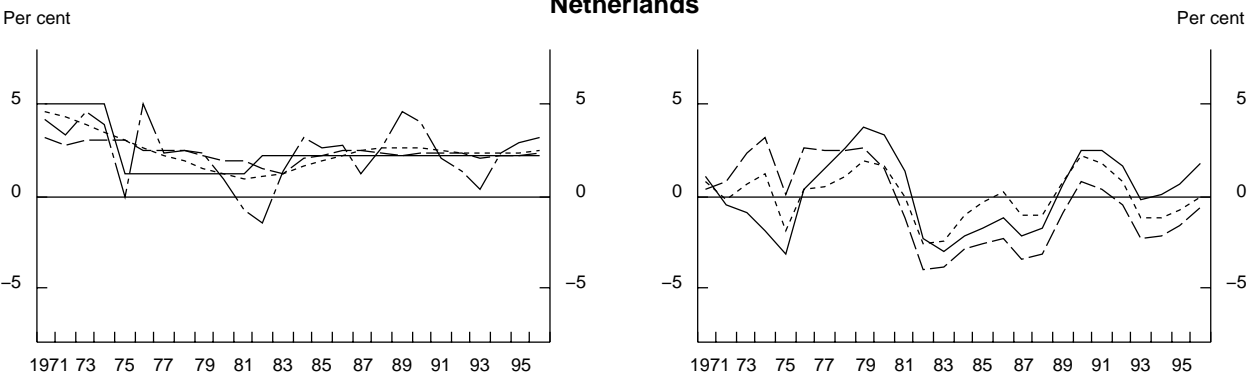

Norway (mainland)

Per cent

Per cent

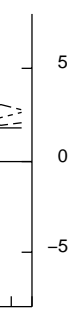

$\begin{array}{lllllllllllll}197173 & 75 & 77 & 79 & 81 & 83 & 85 & 87 & 89 & 91 & 93 & 95\end{array}$

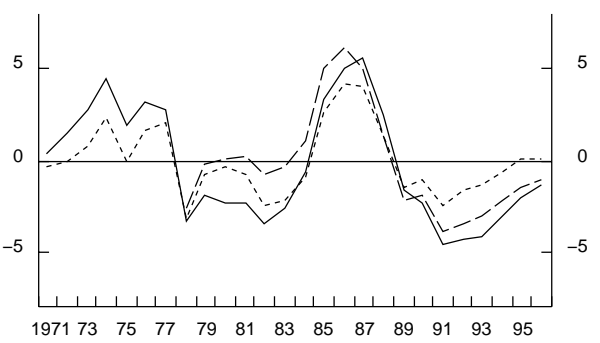

a. Using lambda $=25$.

b. Different scale. 
Figure 1(cont.). Output growth and output gaps

_ Trend GDP: previous method

Trend GDP: HP filter(a)

Potential output

Actual GDP

Output growth

\section{Output gap}

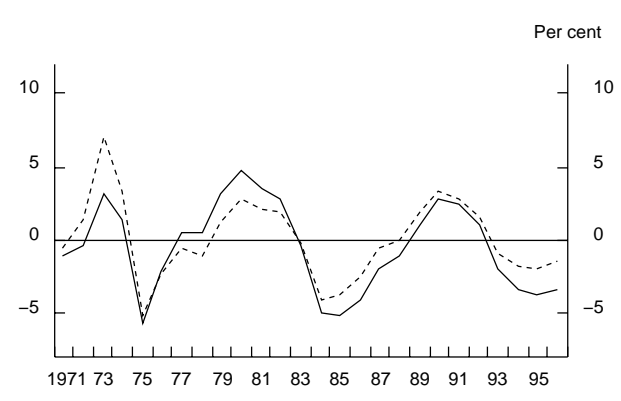

Spain Per cent

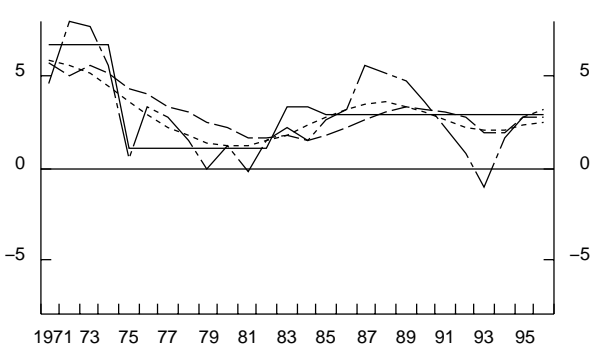

Sweden

a. Using lambda $=25$.

b. Different scale.
Per cent

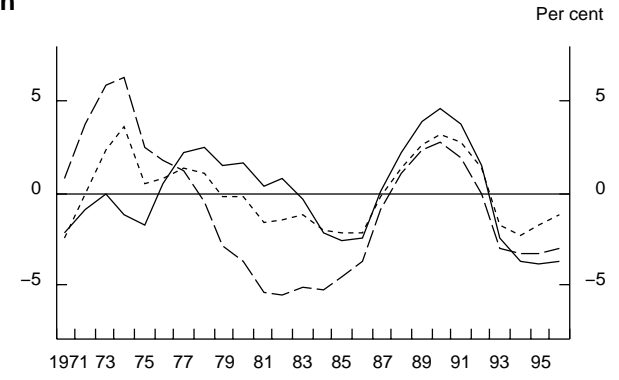

Per cent

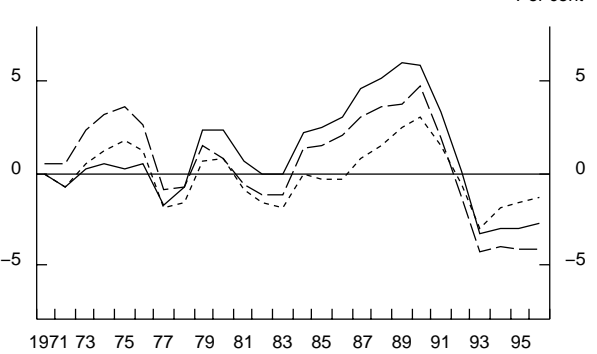


Figure 2. General government structural balances as a percentage of potential GDP(a)

C Previous method, old elasticities Potential, old elasticities. _ _- Potential, new elasticities

United States
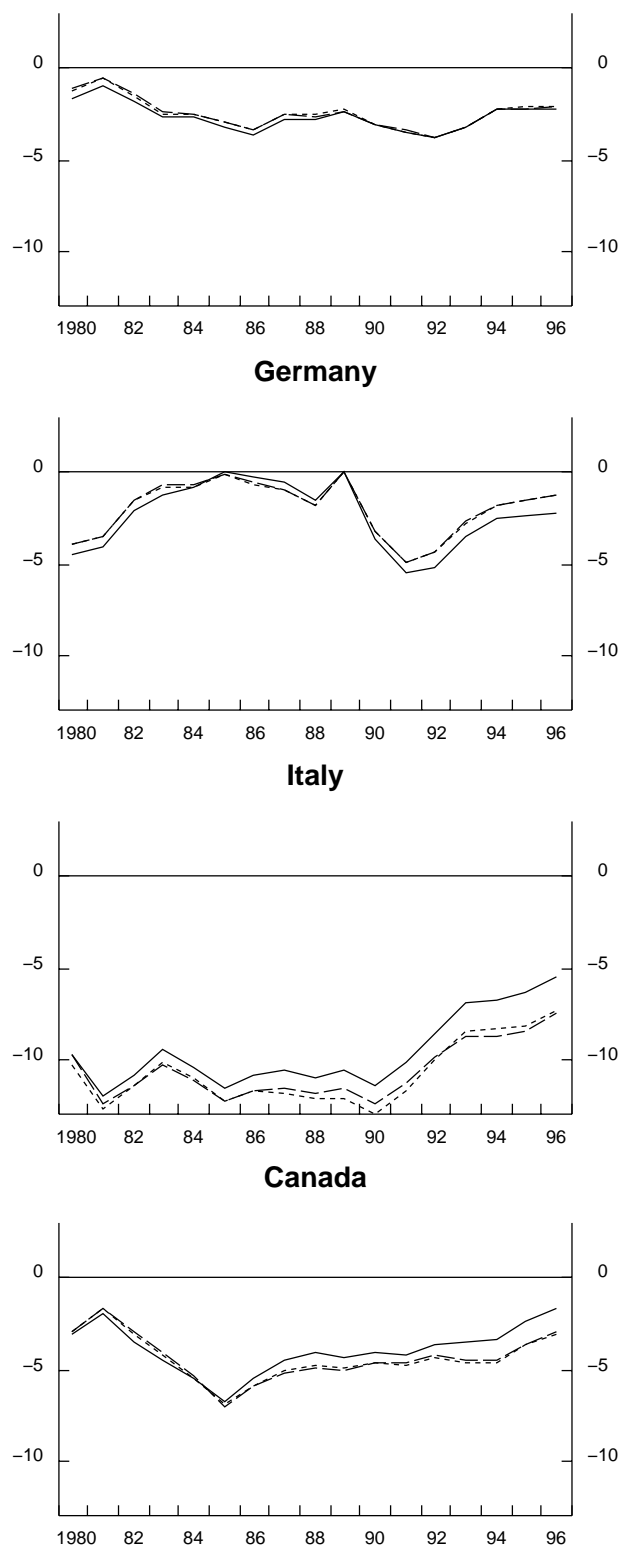

a. Previous method as per cent of trend GDP.
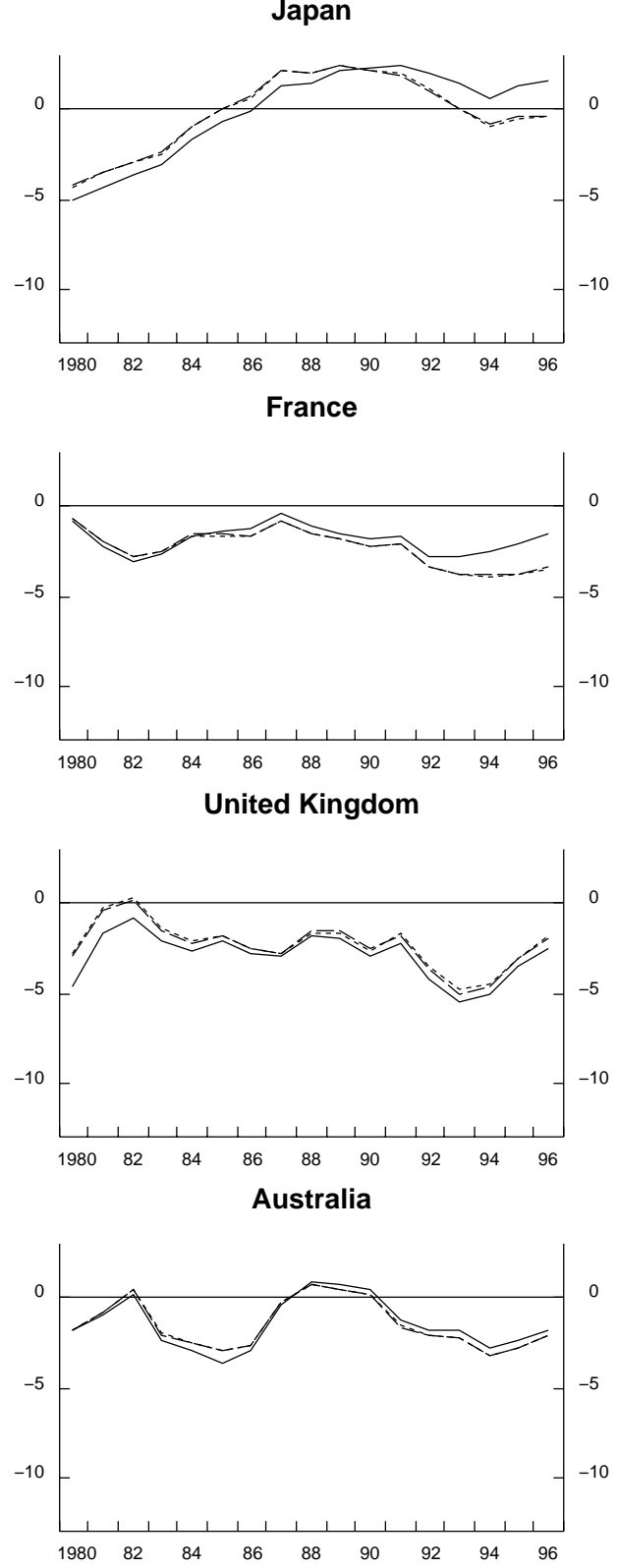
Figure 2 (cont.). General government structural balances As a percentage of potential GDP(a)

_ Previous method, old elasticities

Austria
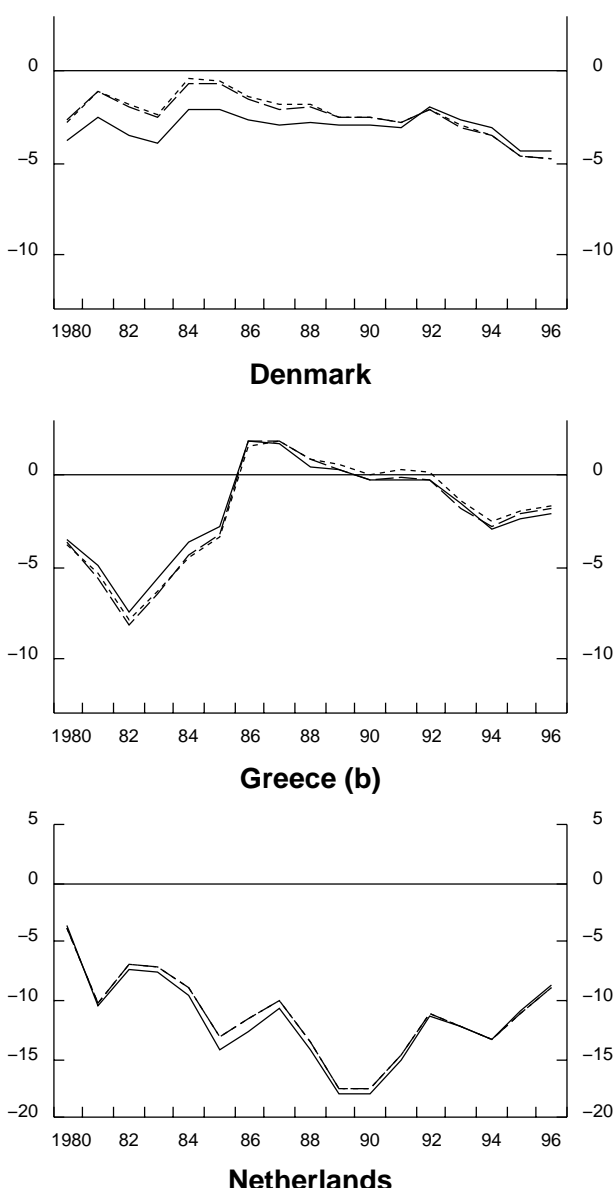

Netherlands

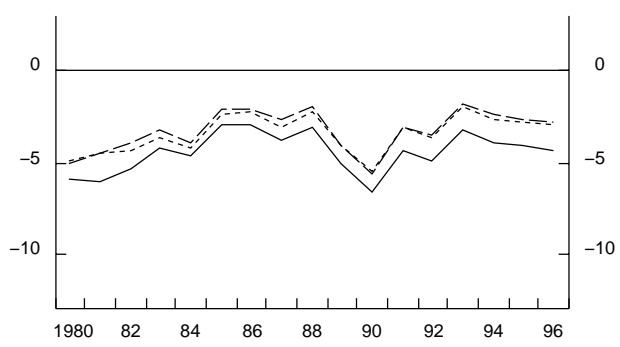

a. Previous method as per cent of trend GDP b. Different scale.

Belgium
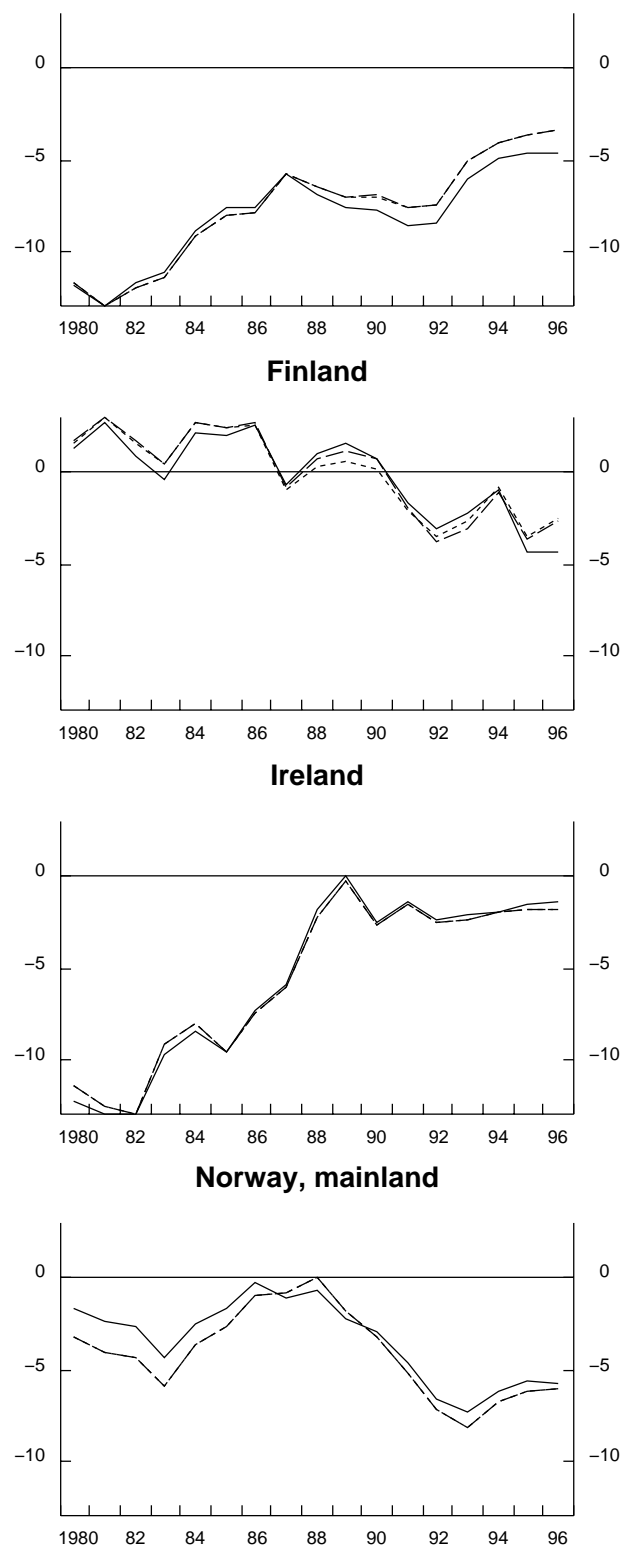
Figure 2 (cont.). General government structural balances As a percentage of potential GDP(a)

_ Previous method, old elasticities _... Potential, old elasticities. _ __ Potential, new elasticities

Portugal (b)
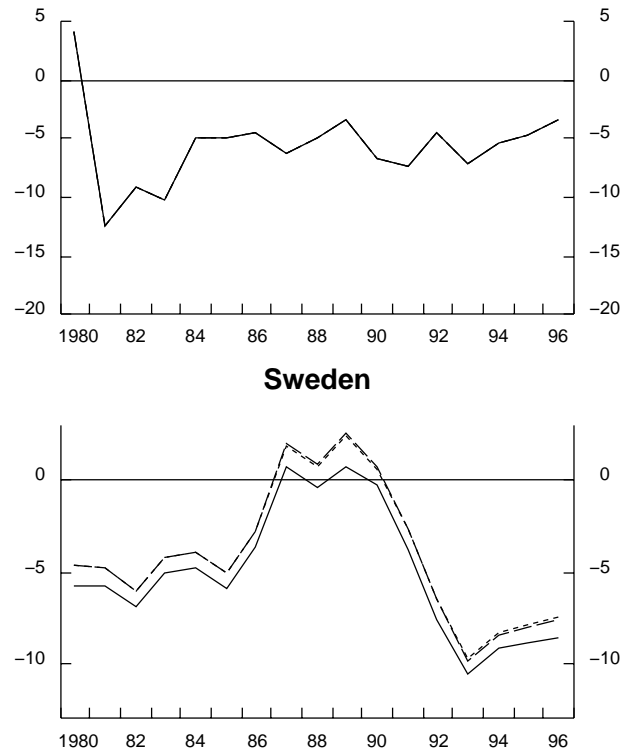

Spain

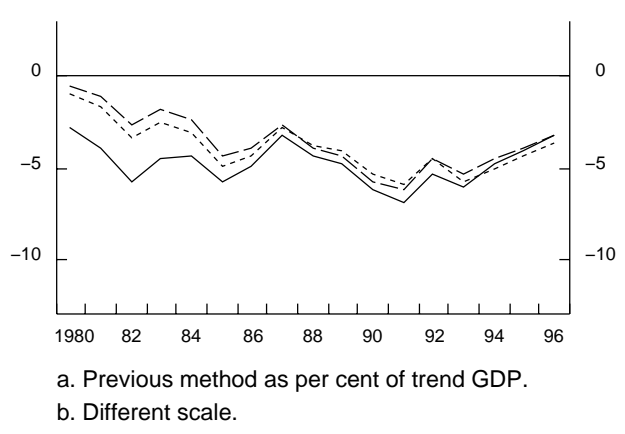




\section{Annex 1 \\ Determination of Income-tax and Social Security Contributions Elasticities}

1. This annex sets out the method that has been used to estimate the output elasticities for household-income tax and social security contributions referred to in Table 5 of the main text. The method involves a number of steps, which will be discussed subsequently below. The first step consists of calculating the marginal and average tax rates (contribution rates) of a representative household at various points on the distribution of gross earnings. The second step is to weight these marginal and average tax rates (contribution rates) together with the weights derived from an estimated income-distribution function. The third and final step is to derive the output (GDP) elasticities of income taxes and social security contributions, allowing for cross-country variation in the responsiveness of employment and wages to fluctuations in real output.

2. The results are rather crude and to be considered as indicative, as a number of simplifying assumptions had to be made. First of all, the representative household is taken to be one consisting of a full-time male worker, a working spouse with gross earnings equalling half of those of her husband, and two children. Second, the calculations refer to "production workers" only, and hence ignore the tax situation of, amongst others, the self-employed. Finally, the income-distribution functions are fitted on a limited number of observations (the first, fifth and ninth deciles), and are held constant over time.

\section{The tax situation of individual households}

3. The average and marginal tax rates at different levels of gross earnings depend on the specific features of the tax system, including tax credits, rebates, tax progression, tax ceilings and tax allowances for a dependent spouse and children, etc. The tax position of individual households on various points of the income distribution have been estimated on the basis of data compiled by DAFFE, modelling the tax systems in 15 individual countries, i.e. the major seven, Australia, Belgium, Denmark, Finland, Netherlands, Norway, Spain and Sweden [see DAFFE/CFA/WP2/WD(93)20]. Simulations have been carried out for 16 points on the distribution of gross earnings, with respect to both income tax and social security contributions, for the years 1978, 1981, 1985, 1989 and 1991, and where data were available also for 1992. Income tax comprises both local and central government taxes and social security contributions include those made by both employees and employers.

\section{The "weighted average" tax situation}

4. In order to calculate the marginal and average rates for an "average" household, the distribution of gross earnings across households has to be established. This distribution, however, is not known for most countries. For each country a log-normal income distribution function could be fitted, on the basis of the two parameters that were known: the ratio of the income level at the first decile to the median income level and the ratio of the ninth decile to the median level (taken from the Employment Outlook of July 1993, Table 5.2). 
5. The weights required to calculate average and marginal tax rates, however, cannot be derived directly from the log-normal distribution function. What is needed is the frequency distribution of currency units earned -- denoted as the "first-moment" distribution. It can be shown that the original distribution and the first-moment distribution have exactly the same standard deviation $(\sigma)$, while the mean of the first-moment distribution exceeds that of the original distribution (u) by the variation coefficient $\left(\sigma^{2}\right)$.

6. The weighted average earnings elasticities, finally, are calculated as follows (Table A1):

$$
\varepsilon=\frac{\Sigma \gamma_{i} \frac{d t_{i}}{d y_{i}}}{\Sigma \gamma_{i} \frac{t_{i}}{y_{i}}}
$$

in which:

$\varepsilon=$ the earnings elasticity of income taxes or social security contributions;

$\Upsilon_{i}=$ the weight of earnings-level $\mathrm{i}$ in total earnings according to the first-moment distribution;

$\mathrm{t}_{\mathrm{i}}=$ income-tax payments (social security contributions) per household at earnings level $\mathrm{i}$;

$\mathrm{y}_{\mathrm{i}}=$ earnings per household at earnings level $\mathrm{i}$;

$\mathrm{dt}_{\mathrm{i}} / \mathrm{dy}_{\mathrm{i}}=$ the marginal tax rate (contribution rate) at point $\mathrm{i}$ on the earnings distribution;

$\mathrm{t}_{\mathrm{i}} / \mathrm{y}_{\mathrm{i}}=$ the average tax rate (contribution rate) at point $\mathrm{i}$ on the earnings distribution.

\section{From earnings- to output-elasticities}

7. Output growth will only to a limited extent be reflected in enhanced earnings and government revenues, as there are a number of "leakages" to be taken into account. First, output growth typically leads to a less than proportional increase in employment due to the presence of hoarded labour within firms. Second, a given rate of growth of employment typically produces a less than proportional increase in wages per household in as much as the number of households earning an income from employment also increases. Third, and related to the second point, an increase in the number of wage earners, a priori, leads to a proportional rather than a progressive increase in payments to the government. If it is assumed that the newly employed are subject to the same distribution of earnings as the already employed, the appropriate elasticity of tax and social security contributions vis-à-vis employment is unity, and the following relationship will hold:

$$
\alpha=\mathrm{EE}(\mathrm{EW} \cdot \varepsilon+1)=\mathrm{EE} \cdot \mathrm{EW} \cdot \varepsilon+\mathrm{EE}
$$

where: $\alpha=$ the output-elasticity of income taxes or social security contributions;

$\varepsilon=$ the earnings elasticity of income taxes or social security contributions;

$\mathrm{EE} \quad=$ the output-elasticity of employment;

$\mathrm{EW}=$ the employment-elasticity of wages.

This formula expresses that the impact of a 1 per cent increase in output on tax proceeds is a composite of two factors: i) an increase in earnings per worker and the associated progressive increase in government proceeds; and ii) an increase in the number of workers in each earnings bracket and the associated proportional increase in government proceeds. 
8. The calculations based on this relationship for 1991 are presented in Table A2 and the results for all years in Table A3. The output-elasticities of employment and the employment-elasticities of wages have been taken from Elmeskov and Pichelmann (1993), with two exceptions. First, for Japan the employment-elasticity of wages has been set at 2 , on the basis of simulations with the new version of the INTERLINK supply block, which accounts for the high responsiveness of overtime (and hence wages per household) to variations in activity [see Turner et al. (1993) for a description of these simulations]. Second, for Australia the employment elasticity of wages has been put at zero, which is probably more realistic than the negative value which is found on the basis of simple regression. 
Table A1. Gross-earnings elasticities of income tax and social security contributions

\begin{tabular}{|c|c|c|c|c|c|c|}
\hline & 1978 & 1981 & 1985 & 1989 & 1991 & 1992 \\
\hline United States & 2.5 & 2.3 & 2.1 & 3.2 & 3.4 & 3.9 \\
\hline Japan & 2.7 & 2.9 & 2.9 & 2.6 & 2.6 & .. \\
\hline Germany & 1.8 & 1.8 & 1.8 & 1.9 & 2.0 & .. \\
\hline France & 2.9 & 3.0 & 3.0 & 3.0 & 3.0 & .. \\
\hline Italy & 1.8 & 1.9 & 1.4 & 2.3 & 1.8 & .. \\
\hline United Kingdom & 1.9 & 1.7 & 1.9 & 1.8 & 1.8 & 1.9 \\
\hline Canada & 2.4 & 2.2 & 2.1 & 1.9 & 1.9 & 1.9 \\
\hline Australia & 2.0 & 1.7 & 1.8 & 1.8 & 1.7 & 1.7 \\
\hline Belgium & 3.6 & 2.0 & 1.9 & 2.3 & 2.2 &.. \\
\hline Denmark & 1.5 & 1.4 & 1.5 & 1.4 & 1.4 & .. \\
\hline Finland & 1.7 & 1.7 & 1.7 & 1.9 & 1.8 & .. \\
\hline Netherlands & 2.1 & 2.2 & 1.8 & 1.9 & 1.8 & $\begin{array}{l}. . \\
.\end{array}$ \\
\hline Norway & 1.8 & 1.8 & 1.9 & 1.7 & 1.7 & .. \\
\hline Spain & 2.8 & 2.4 & 2.8 & 3.7 & 4.1 & .. \\
\hline \multirow[t]{2}{*}{ Sweden } & 1.6 & 1.5 & 1.4 & 1.4 & 1.3 & .. \\
\hline & \multicolumn{6}{|c|}{ Social Security contributions } \\
\hline United States & 0.8 & 1.0 & 1.0 & 1.0 & 1.0 & 1.0 \\
\hline Japan & 1.0 & 1.0 & 1.0 & 1.0 & 1.0 &.. \\
\hline Germany & 0.9 & 0.9 & 0.9 & 0.9 & 0.9 & .. \\
\hline France & 0.8 & 0.8 & 0.9 & 0.9 & 0.9 & .. \\
\hline Italy & 1.0 & 1.0 & 1.0 & 1.0 & 1.0 &.. \\
\hline United Kingdom & 0.9 & 0.9 & 1.0 & 1.1 & 1.1 & $\ddot{1.1}$ \\
\hline Canada & 0.6 & 0.6 & 0.7 & 0.8 & 0.8 & 0.8 \\
\hline Australia &.. &.. & 1.0 & 1.7 & 1.0 & 1.0 \\
\hline Belgium & 0.9 & $\ddot{1.0}$ & 1.0 & 1.0 & 1.0 &.. \\
\hline Denmark & 0.9 & 0.9 & 0.7 & 0.0 & 0.0 & .. \\
\hline Finland & 1.0 & 1.0 & 1.0 & 1.1 & 1.2 & .. \\
\hline Netherlands & 1.1 & 1.1 & 1.1 & 1.1 & 1.0 & .. \\
\hline Norway & 1.0 & 1.0 & 1.0 & 1.0 & 1.0 & .. \\
\hline Spain & 0.7 & 0.8 & 0.8 & 0.8 & 0.8 & .. \\
\hline Sweden & 1.0 & 1.0 & 1.0 & 1.0 & 1.0 &.. \\
\hline
\end{tabular}


Table A2. Output elasticities of income tax and social security contributions in 1991

\begin{tabular}{|c|c|c|c|c|c|c|c|}
\hline & \multicolumn{2}{|c|}{$\begin{array}{l}\text { Earnings } \\
\text { elasticity of }\end{array}$} & \multirow[b]{2}{*}{$\begin{array}{l}\text { Output- } \\
\text { elasticity of } \\
\text { employ. }\end{array}$} & \multirow[b]{2}{*}{$\begin{array}{l}\text { employ. } \\
\text { elasticity of } \\
\text { wages }\end{array}$} & \multirow[b]{2}{*}{$\begin{array}{l}\text { Output- } \\
\text { elasticity of } \\
\text { wages }\end{array}$} & \multicolumn{2}{|c|}{$\begin{array}{c}\text { Output elasticity } \\
\text { of }\end{array}$} \\
\hline & $\begin{array}{l}\text { Income } \\
\text { tax }\end{array}$ & $\begin{array}{c}\text { Social } \\
\text { security } \\
\text { contrib. }\end{array}$ & & & & $\begin{array}{c}\text { Income } \\
\operatorname{tax}\end{array}$ & $\begin{array}{c}\text { Social } \\
\text { security }\end{array}$ \\
\hline & \multicolumn{2}{|c|}{ (1) } & (2) & (3) & $(4)=(2) \times(3)$ & \multicolumn{2}{|c|}{$(5)=(1) \times(4)+(2)$} \\
\hline United States & 3.4 & 1.0 & 0.64 & 0.26 & 0.17 & 1.2 & 0.8 \\
\hline Japan & 2.6 & 1.0 & 0.19 & 2.00 & 0.38 & 1.2 & 0.6 \\
\hline Germany & 2.0 & 0.9 & 0.45 & 0.57 & 0.26 & 1.0 & 0.7 \\
\hline France & 3.0 & 0.9 & 0.38 & 0.90 & 0.34 & 1.4 & 0.7 \\
\hline Italy & 1.8 & 1.0 & 0.15 & 0.74 & 0.11 & 0.3 & 0.3 \\
\hline United Kingdom & 1.8 & 1.1 & 0.68 & 0.51 & 0.35 & 1.3 & 1.1 \\
\hline Canada & 1.9 & 0.8 & 0.62 & 0.32 & 0.20 & 1.0 & 0.8 \\
\hline Australia & 1.7 & 1.0 & 0.79 & 0.00 & 0.00 & 0.8 & 0.8 \\
\hline Belgium & 2.2 & 1.0 & 0.49 & 0.63 & 0.31 & 1.2 & 0.8 \\
\hline Denmark & 1.4 & 0.0 & 0.59 & 0.10 & 0.06 & 0.7 & 0.6 \\
\hline Finland & 1.8 & 1.2 & 0.37 & 1.18 & 0.44 & 1.2 & 0.9 \\
\hline Netherlands & 1.8 & 1.0 & 0.63 & 0.52 & 0.33 & 1.2 & 1.0 \\
\hline Norway & 1.7 & 1.0 & 0.63 & 0.47 & 0.30 & 1.1 & 0.9 \\
\hline Spain & 4.1 & 0.8 & 0.85 & 0.38 & 0.32 & 2.2 & 1.1 \\
\hline Sweden & 1.3 & 1.0 & 0.50 & 1.33 & 0.67 & 1.3 & 1.2 \\
\hline
\end{tabular}


Table A3. Output elasticities of income tax and social contributions

\begin{tabular}{|c|c|c|c|c|c|c|}
\hline & 1978 & 1981 & 1985 & 1989 & 1991 & 1992 \\
\hline United States & 1.1 & 1.0 & 1.0 & 1.2 & 1.2 & 1.3 \\
\hline Japan & 1.2 & 1.3 & 1.3 & 1.2 & 1.2 & .. \\
\hline Germany & 0.9 & 0.9 & 0.9 & 0.9 & 1.0 & .. \\
\hline France & 1.4 & 1.4 & 1.4 & 1.4 & 1.4 & .. \\
\hline Italy & 0.4 & 0.4 & 0.3 & 0.4 & 0.3 & .. \\
\hline United Kingdom & 1.4 & 1.3 & 1.3 & 1.3 & 1.3 & 1.3 \\
\hline Canada & 1.1 & 1.1 & 1.0 & 1.0 & 1.0 & 1.0 \\
\hline Australia & 0.8 & 0.8 & 0.8 & 0.8 & 0.8 & 0.8 \\
\hline Belgium & 1.6 & 1.1 & 1.1 & 1.2 & 1.2 &.. \\
\hline Denmark & 0.7 & 0.7 & 0.7 & 0.7 & 0.7 & .. \\
\hline Finland & 1.1 & 1.1 & 1.1 & 1.2 & 1.2 & .. \\
\hline Netherlands & 1.3 & 1.3 & 1.2 & 1.3 & 1.2 & .. \\
\hline Norway & 1.2 & 1.2 & 1.2 & 1.1 & 1.1 & .. \\
\hline Spain & 1.7 & 1.6 & 1.8 & 2.0 & 2.2 & .. \\
\hline \multirow[t]{2}{*}{ Sweden } & 1.5 & 1.5 & 1.4 & 1.4 & 1.3 & .. \\
\hline & \multicolumn{6}{|c|}{ Social Security contributions } \\
\hline United States & 0.8 & 0.8 & 0.8 & 0.8 & 0.8 & 0.8 \\
\hline Japan & 0.6 & 0.6 & 0.6 & 0.6 & 0.6 &.. \\
\hline Germany & 0.7 & 0.7 & 0.7 & 0.7 & 0.7 & .. \\
\hline France & 0.7 & 0.7 & 0.7 & 0.7 & 0.7 & .. \\
\hline Italy & 0.3 & 0.3 & 0.3 & 0.3 & 0.3 & .. \\
\hline United Kingdom & 1.0 & 1.0 & 1.0 & 1.0 & 1.1 & 1.1 \\
\hline Canada & 0.7 & 0.7 & 0.8 & 0.8 & 0.8 & 0.8 \\
\hline Australia &.. &.. & 0.8 & 0.8 & 0.8 & 0.8 \\
\hline Belgium & 0.8 & 0.8 & 0.8 & 0.8 & 0.8 &.. \\
\hline Denmark & 0.6 & 0.6 & 0.6 & 0.6 & 0.6 &.. \\
\hline Finland & 0.8 & 0.8 & 0.8 & 0.8 & 0.9 &.. \\
\hline Netherlands & 1.0 & 1.0 & 1.0 & 1.0 & 1.0 &.. \\
\hline Norway & 0.9 & 0.9 & 0.9 & 0.9 & 0.9 &.. \\
\hline Spain & 1.1 & 1.1 & 1.1 & 1.1 & 1.1 &.. \\
\hline Sweden & 1.2 & 1.2 & 1.2 & 1.2 & 1.2 & .. \\
\hline
\end{tabular}




\section{References}

BLANCHARD, O., "Suggestions for a new set of fiscal indicators", OECD Department of Economics and Statistics Working Paper No. 79, 1990.

CANOVA, F., "Detrending and business cycle facts", CEPR Discussion Paper No. 782, 1993.

CHOURAQUI, J.C., R. HAGEMANN and N. SARTOR, "Indicators of fiscal policy: a reexamination", OECD Department of Economics and Statistics Working Paper No. 78, 1990.

ELMESKOV, J. and M. MACFARLAN, "Unemployment persistence", OECD Economic Studies, No. 21 (Winter 1993).

ELMESKOV, J., "High and persistent unemployment: assessment of the problem and its causes", OECD Economics Department Working Paper No. 132, 1993.

HODRICK, R. and E. PRESCOTT, "Post-war US business cycles: an empirical investigation", Working Paper, Carnegie Mellon University, 1980.

KYDLAND F. and C. PRESCOTT, "Business cycles: real facts and a monetary myth", Federal Reserve Bank of Minneapolis, Quarterly Review (Spring), pp 3-18, 1990.

NELSON, C. and C.I. PLOSSER, "Trends and random walks in macroeconomic series", Journal of Monetary Economics 10, pp 139-162, 1982.

OECD, Working Party No. 2 on Tax Analysis and Tax Statistics of the Committee of Fiscal Affairs, Tax Equation Spreadsheets, Paris, 1993 [DAFFE/CFA/WP2/WD(93)20].

OECD, Employment Outlook, Paris, July 1993.

PRICE, W.R. and P. MULLER, "Structural budget indicators and the interpretation of fiscal policy stance in OECD economies", OECD Economic Studies, No. 3, Autumn 1994.

TORRES, R and J.P. MARTIN, "Potential output in the seven major OECD countries", OECD Economic Studies No. 14, Spring 1990, pp 127-149.

TORRES, R., P. JARRETT and W. SUYKER, "Modelling business sector supply for the smaller OECD countries", Department of Economics and Statistics Working Paper No. 71, 1989.

TURNER, D., P. RICHARDSON and S. RAUFFET, "The role of real and nominal rigidities in macroeconomic adjustment", OECD Economic Studies, No. 21, Winter 1993.

TURNER, D., P. RICHARDSON and S. RAUFFET, "Modelling the supply side of the seven major OECD economies", OECD Economics Department Working Paper (forthcoming). 